ISSN (print): 1698-6180. ISSN (online): 1886-7995

www.ucm.es/info/estratig/journal.htm

Journal of Iberian Geology 38 (2) 2012: 407-428

http://dx.doi.org/10.5209/rev_JIGE.2012.v38.n2.40466

\title{
Interaction between intra-continental sedimentary basins and small-volume monogenetic volcanism: Argamasilla and Calzada- Moral basins, Campo de Calatrava Volcanic Field, Spain
}

\author{
Interacción entre cuencas sedimentarias intra-continentales y volcanismo \\ monogenético de pequeño volumen: Cuencas de Argamasilla y Calzada-Moral - \\ Región Volcánica del Campo de Calatrava, España
}

\author{
A. Herrero-Hernández ${ }^{1 *}$, F.J. López-Moro², F. Gómez-Fernández ${ }^{3}$, A. Martín-Serrano ${ }^{4}$ \\ ${ }^{1}$ Grupo de Investigación en Ingeniería y Medio Ambiente (INGEMAT). Escuela Superior y Técnica de Ingeniería Agraria. \\ Universidad de León. C/ Avenida de Portugal 41,24071 León, Spain.aherrero@icog.es \\ ${ }^{2}$ Dept. de Geología, Facultad de Ciencias, Universidad de Salamanca, Plaza de Los Caídos s/n, 37008 Salamanca, Spain. \\ fjlopezmoro@me.com \\ ${ }^{3}$ Dept. de Tecnología Minera, Topográfica y de Estructuras. Universidad de León. C/ Jesús Rubio 2, 24004-León, Spain. \\ f.gomez@unileon.es \\ ${ }^{4}$ Instituto Geológico y Minero de España (IGME), La Calera s/n, E-28760-Tres Cantos, Madrid, Spain. \\ a.martinserrano@igme.es \\ *corresponding author
}

Received: 13/01/2011 / Accepted: 15/10/2012

\begin{abstract}
We study the volcaniclastic lithofacies interbedded between siliciclastic and carbonate sediments of Cenozoic-Quaternary age (8.7 Ma to 7,000 BP) in Argamasilla and Calzada-Moral basins (Central Spain). The siliciclastic and carbonate deposits correspond to fluvio-lacustrine sedimentary environments. The volcanic materials consist of primary and reworked volcaniclastic successions sourced from the Campo de Calatrava Volcanic Field. Pyroclastic deposits are related to monogenetic and small-volume volcanic centres, such as scoria cones, tuff rings and maars, corresponding to Strombolian and phreatomagmatic eruptive styles.

Taking into account sedimentological constraints seven volcaniclastic lithofacies were distinguished. Type A corresponds to subaerial pyroclastic fall deposits, as is inferred by the common disorganization of the deposit, their breccia-like aspect with presence of large bombs, poor sorting and lack of tractional sedimentary structures. Types B1, B2, B3 and B4 have different volcanic sources and are interpreted to be the product of low-density (dilute) pyroclastic surges, with textural features indicative of fluctuations in flow regime. This interpretation is based on the fabric and grain size of pyroclasts, together with the size and geometry of the internal sedimentary structures. Type $\mathrm{C}$ represents a secondary volcanic deposit related to volcanic sediments reworked by transitional hyperconcentrated flows and dilute fluvial processes, having subsequently accumulated in braided fluvial systems. Finally, the Type $\mathrm{D}$ is interpreted as an intra-maar scoria/spatter cones related to the development of maars.
\end{abstract}


The most important factors that determined the sedimentation in these basins were orientation of basement faults, paleogeographic and sedimentological controls, style of eruption and volcaniclastic lithofacies type.

Keywords: Pyroclastic fall, dilute pyroclastic base surge, phreatomagmatic eruption, maar, tuff ring, sedimentary control

Resumen

Se presenta un estudio de las litofacies volcanoclásticas intercaladas entre sedimentos siliclásticos y carbonatados de edad Cenozoica y Cuaternaria (8,7 Ma a 7.000 BP) en las cuencas de Argamasilla y de Calzada-Moral (centro de España). Los depósitos carbonatados y siliciclásticos corresponden a ambientes sedimentarios fluvio-lacustres. Los materiales volcánicos se componen de sucesiones primarias y retrabajadas originadas en el Campo Volcánico del Campo de Calatrava. Los depósitos piroclásticos están relacionados con centros volcánicos monogenéticos y de pequeño volumen, como conos de escoria, anillos de tobas y maars, correspondientes a erupciones estrombolianas y freatomagmáticas.

Teniendo en cuenta el análisis sedimentológico se han distinguido siete litofacies volcanoclásticas. El Tipo A corresponde a depósitos de caída piroclástica subaérea, como se infiere por la desorganización común del depósito, su aspecto de breccia con presencia de grandes bombas, mala clasificación y la ausencia de estructuras sedimentarias de tracción. Los tipos B1, B2, B3 y B4 tienen diferentes fuentes volcánicas y se interpretan como productos de oleadas piroclásticas de baja densidad (diluidas), con características texturales indicativas de las fluctuaciones del régimen de flujo. Esta interpretación se basa en el tamaño de grano de los piroclastos, y el tamaño y la geometría de las estructuras sedimentarias internas. El Tipo C representa un depósito volcánico secundario relacionado con sedimentos volcánicos retrabajados por flujos hiperconcentrados de transición y procesos fluviales diluidos, habiéndose acumulado posteriormente en sistemas fluviales trenzados. Por último, el Tipo D se interpreta como un cono de escoria/salpicaduras intra-maar relacionado con el desarrollo de un maar.

Los principales factores que determinaron la sedimentación en estas cuencas fueron la orientación de las fallas del basamento, los controles sedimentológicos y paleogeográficos, así como el estilo eruptivo y el tipo de litofacies volcanoclástica.

Palabras clave: Piroclastos de caída, oleadas basales piroclásticas diluidas, erupción freatomagmática, maar, anillo de tobas, control sedimentario

\section{Introduction}

The eruption of basalts is the most common form of volcanism on the Earth's surface, especially in tectonically active zones and continental/intraplate zones (Valentine and Gregg, 2008). Cenozoic alkaline mafic magmas erupted in different regions of Europe defining the Tertiary Central European Volcanic Province (Wilson and Downes, 1991) and the Circum-Mediterranean Anorogenic Cenozoic Igneous Province (Lustrino and Wilson, 2007; Lustrino et al., 2011). In both provinces different intra-continental volcanic fields were developed, namely in Eifel, Germany (e.g. Seib et al., 2008), in the Pannonian Basin, in Central Europe (e.g. Kereszturi et al., 2011), in the Eger Graben, Czech Republic (e.g. Cajz et al., 2009), or in the Iberian Peninsula (Alborán Sea, Campo de Calatrava, Levante and the SE Volcanic Province, see López Ruiz et al., 2002). Coevally with the Cenozoic volcanism it is not uncommon to found a continental sedimentation that occurred in basins formed during the Alpine Orogeny. This coexistence provides the occurrence of volcanic and non-volcanic deposits, as it has been reported in different geotectonic and paleoenvironmental settings, including large-volume stratovolcanoes, calderas and small-volume monogenetic volcanic fields (e.g. Smith, 1987, 1991; White, 1990, 1991; Haughton, 1993; Eriks- son and Simpson, 1993; Hayes et al., 2002; Gran and Montgomery, 2005; Kataoka, 2005; and Martina et al., 2005; Manville et al., 2009).

In the case of the Iberian Peninsula, different continental sedimentary basins were formed during the Alpine Orogeny, namely, Duero, Tajo, Ebro and La Mancha basins. In the latter, a number of associated depressions (Argamasilla and Calzada-Moral basins, Fig. 1) exhibit volcaniclastic deposits interbedded between continental deposits (Herrero et al., 2004 a, b; Herrero et al., 2009). Although abundant literature on volcaniclastic deposits exists regarding the transport processes and types of deposits (e.g., McPhie et al., 2001; Németh et al., 2009; Manville et al., 2009), there is scarce information about the influence of volcanism on continental basins, being, therefore, an issue poorly understood, which is in line with the lack of systematic volcanological and sedimentological studies in the above basins.

This work focuses on the description, interpretation and correlation of the volcaniclastic deposits of the Argamasilla and Calzada-Moral basins located in the Campo de Calatrava Volcanic Field, which will give us guidelines for establishing their relationship with the sedimentary and tectonic evolution of these basins. To achieve these goals we discuss twenty-two detailed stratigraphic profiles of selected outcrops, where volcaniclastic lithofacies have been identified. Data con- 


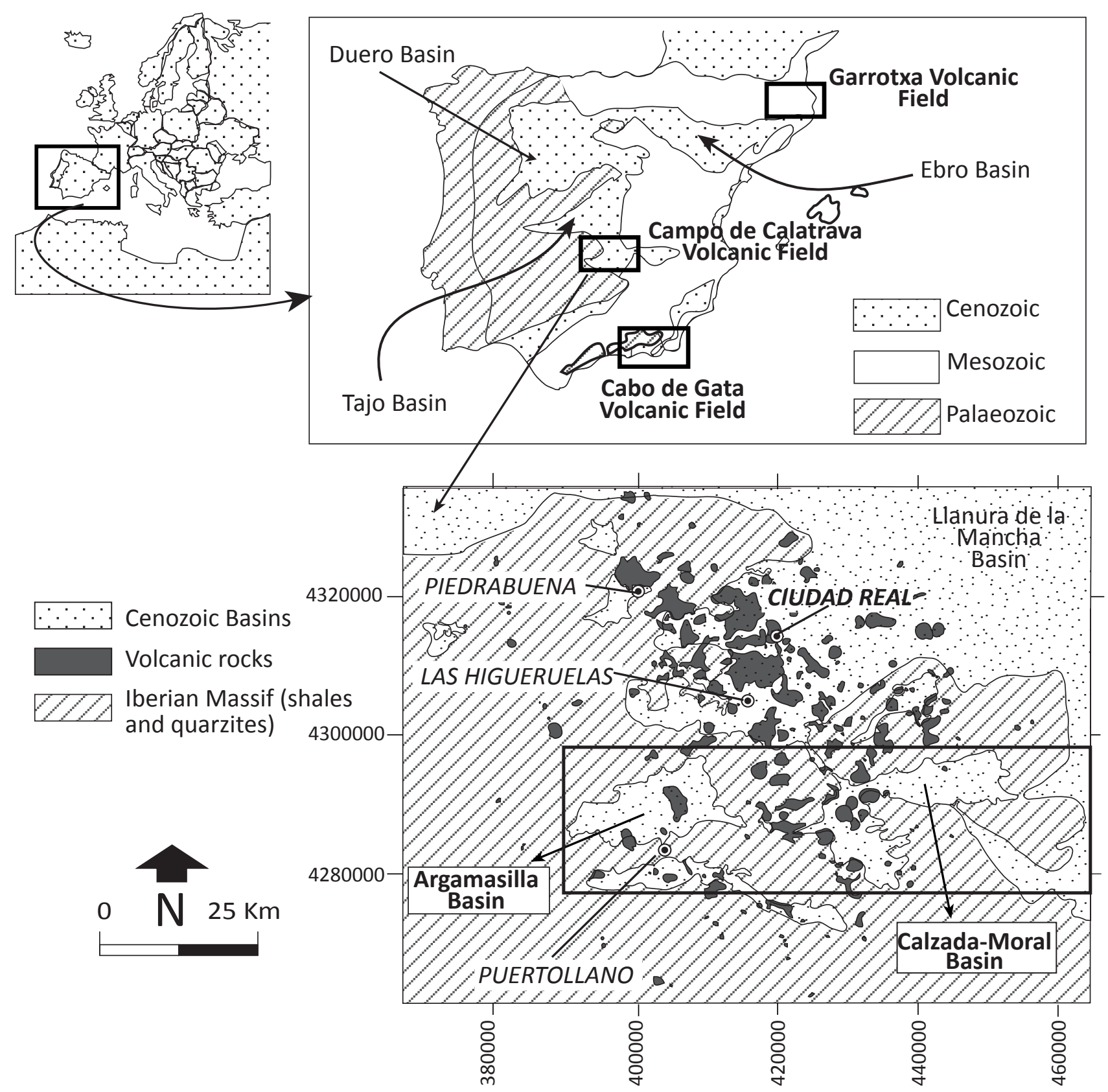

Fig. 1.- Location of the main Neogene basins and volcanic fields in the Iberian Peninsula. General geology of the Campo de Calatrava Volcanic Field, modified from Gallardo-Millán and Pérez-González (2000).

Fig. 1.- Localización de las principales cuencas neógenas y regiones volcánicas en la Península Ibérica. Geología general de la Región Volcánica del Campo de Calatrava, modificada a partir de Gallardo-Millán y Pérez-González (2000).

tain volcaniclastic successions, including classification of lithology, measurement of grain-size of particles, colour, bed thickness, overall rock texture, mean and maximum grain size, sedimentary structures and measurements of paleocurrent indicators. The analysis of the sedimentary processes that produced the volcaniclastic deposits interbedded between siliciclastic and carbonate sediments will provide a generalised facies model of intra-continental terrestrial sedimentation influenced by a monogenetic volcanism.

\section{Geological setting}

The sedimentary basins of Argamasilla and CalzadaMoral are located over the Variscan basement of the socalled Iberian Massif (Fig. 1). The most relevant works analysing the region are those of Molina $(1975,1980)$, Molina et al., (1972), Crespo (1988, 1992) and Palero (1991). Basement structural features (folds and faults), with a general east-west trend, are conditioning the present regional relief. The reactivation of NNW-SSE 
and ENE-WSW fault systems during the Alpine Orogeny is considered to have produced the subsidence recorded by its sedimentary filling. These basins are mainly surrounded by ranges of mountains consisting of Ordovician and Silurian metasediments, which constitute the supplies for the basin-filling process. Fossil-bearing deposits in Cenozoic basins located northwards of those analysed here, namely, at Piedrabuena and Las Higueruelas (Fig. 1), have led to an attempt at correlation and dating of Argamasilla and Calzada-Moral, obtaining similar ages to those obtained from absolute dating in volcanic rocks (8.7 to $0.7 \mathrm{Ma}$, e.g., Ancochea 2004). The deposits of these basins are related to fluvial, lacustrine and palustrine environments, soil alteration (calcretes) and a remarkable proportion to volcanic supplies from the so-called Campo de Calatrava Volcanic Field (CCVF). The eruptive style for the CCVF is dominated by small-volume explosive eruptions, typically Strombolian and phreatomagmatic (Di Traglia et al., 2009). Two phases of volcanism have been distinguished in this area (Ancochea 2004): a first ultrapotassic episode occurring between 8.7 and $6.4 \mathrm{Ma}$ (Upper Miocene), and a second episode, alkaline and ultraalkaline in composition, dated between 3.7 and 0.7 Ma (Plio-Pleistocene, e.g., Ancochea et al., 1979; Ancochea and Ibarrola, 1982; Bonadonna and Villa 1984; Gallardo-Millán et al., 2002; Gallardo-Millán, 2004). Finally, a late-stage phreatomagmatic has been dated at the mid-Holocene (Columba volcano, Fig. 1, see GonzálezCárdenas et al., 2007, 2008). The volcanism in the CCVF was typically monogenetic according to its short live and small volumes (see e.g., Valentine and Gregg, 2008, Németh, 2010), producing small-volume volcanic edifices of scoria cones, tuff rings and maars. The most common eruption style is the Strombolian, showing 200 and 350 vents that are aligned NNW-SSE, generally in the preferential directions of N45-60W, N40E and N80-85E (Barrera, 1996; Rodríguez Pascua and Barrera, 2002 and Ancochea, 2004).

Numerous hypotheses have been invoked to explain the mechanism triggering volcanism in the CCVF, namely, a transform fault located between the Betic Orogen and the Central Spanish Plateau (Doblas et al., 1991), an extensional model associated with rifting processes (López Ruiz et al., 1993) and lithospheric flexures that involved the mantle as a consequence of the Betic Orogen (Rincón and Vegas, 1996).

\section{Sedimentary successions in the Argamasilla and Calzada-Moral basins}

Besides volcaniclastic facies, described in detail below, the sedimentary succession in the Argamasilla
Basin mainly comprises gravels, sands, clays and limestones, with a maximum thickness of $50-70 \mathrm{~m}$. The sedimentary environments correspond to braided river systems, with longitudinal and transverse gravel bars within low-sinuosity fluvial channels and a moderateto-high braided component (Monteserín et al., 2011; Martín-Serrano et al., 2011 and Martín Banda et al., 2011). Flood plain deposits are mainly formed by sands and were generated by overbank deposition. The channel network is interpreted to be ephemeral and mobile, as it can be deduced from the pattern of channel and overbank facies, with a maximum of one or two superimposed sequences of conglomerates surrounded by flood plain deposits. Flood plains show evidences of subaerial exposures and processes of soil alteration (calcretes). In the southeast of the basin, carbonate-rich lacustrine and palustrine environments occur, with different marginal, littoral, and open lake facies (profiles 1 and 2, Fig. 3).

Complementary information about Neogene sediment thickness has been provided from the ARG-1 borehole, located close to Argamasilla de Calatrava (Figs. 3 and 4A), obtaining a minimum thickness of $105 \mathrm{~m}$ for this basin.

Calzada-Moral Basin is constituted by fine-grained terrigenous material, namely, clays and sands, as well as calcretes, conglomerate beds, marls and scarce limestones. The coarse sediments were deposited in low-sinuosity, mono-episodic, and ephemeral fluvial channels. The existence of sigmoidal lateral accretion units in some bars indicates high-sinuosity channels. Fine-grained materials represent the sedimentation in a flood plain, where pedogenic processes occurred (profiles 3, 9, 10, 11 and 12; Fig. 5).

Using available subsoil data, two depocentres were identified in the Calzada-Moral Basin. The shallowest depocentre is placed close to Moral de Calatrava (Fig. 5), having a maximum depth of $150 \mathrm{~m}$. The deepest one is close to Aldea del Rey, where its maximum depth has been estimated to be around $300 \mathrm{~m}$ (Fig. 2). The thickness of Neogene sediments decreases towards the NE, as it is inferred from the $811 / 1$ borehole (Fig. 2A), where a maximum thickness of $184.50 \mathrm{~m}$ was reached in these sediments (Fig. 4 B).

\section{Sedimentological analysis of the volcaniclastic deposits}

In this section, volcaniclastic deposits interbedded with siliciclastic and carbonate sediments of the Argamasilla and Calzada-Moral basins are described and interpreted, the description of volcaniclastic lithofacies and sequences being summarized in Table 1. 

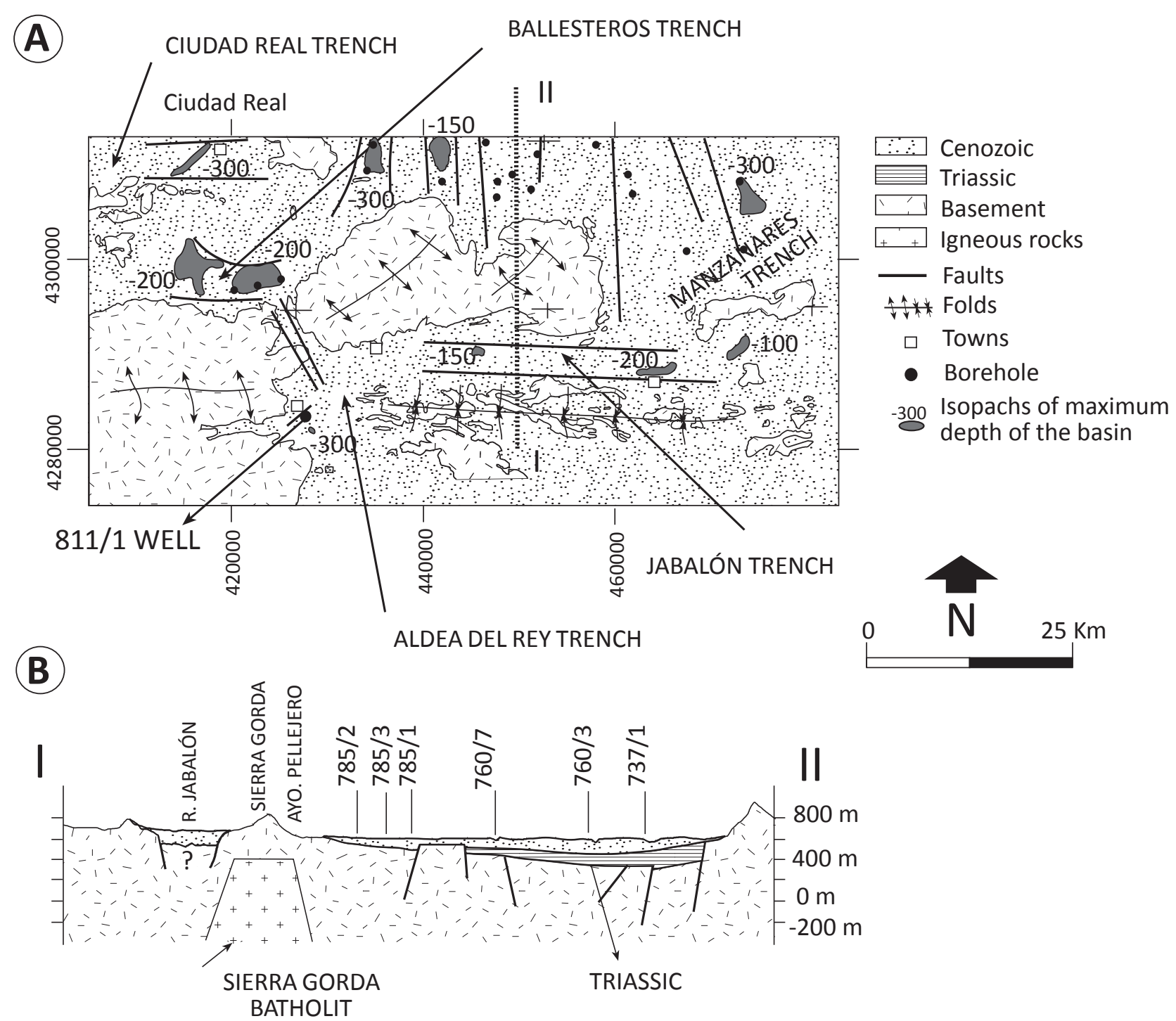

Fig. 2.- Isobaths and structural maps of the Campo de Calatrava. Modified after Rosales et al. (1988). A) Structural map of the Campo de Calatrava region. B) N-S geological sections.

Fig. 2.- Mapas de isobatas y estructural del Campo de Calatrava. Modificado a partir de Rosales et al. (1988). A) Mapa estructural de la región del Campo de Calatrava. B) Cortes geológicos en dirección N-S.

\subsection{Type A volcaniclastic deposit (A)}

This deposit is recorded at Granátula de Calatrava (Calzada-Moral Basin) (Fig. 6) and is composed of two distinct stratigraphy horizons covered by the Type B3 deposits (described below). The lower part of the deposit is a volcanic breccia (formed of lapilli, blocks and bombs) (Fig. 7A) sometimes joined at one or two points between particles (Table 1). These materials are polymodal, with a main size of $20-25 \mathrm{~cm}$. They show clast-supported texture, with matrix (sometimes open framework) of coarse ash and reddish fine lapilli, without any orientation of blocks. The deposit is poorly sorted and shows a nonuniform distribution of grain sizes. Outsized blocks, of up to $1 \mathrm{~m}^{3}$, are arranged sparsely between the rest of the clasts (Fig. 7B). Most of the pyroclasts are welded in this lithofacies and form an indurated level (Fig. 7B). Internally, materials are disorganised, massive to weakly bedded and normal graded. The lateral extension of this volcaniclastic deposit is less than $500 \mathrm{~m}$.

The components are primary juvenile clasts, most of them with angular to irregular shapes. Slightly vesiculated blocks and angular shapes, locally showing subrounded rims, are abundant, being mainly formed by plagioclase-rich basalts and limburgites (Martín-Serrano et al., 2011).

The upper part is made up of red clays (10 R 4/6) with ash, together with scattered blocks and bombs. These 
GENERAL LEGEND

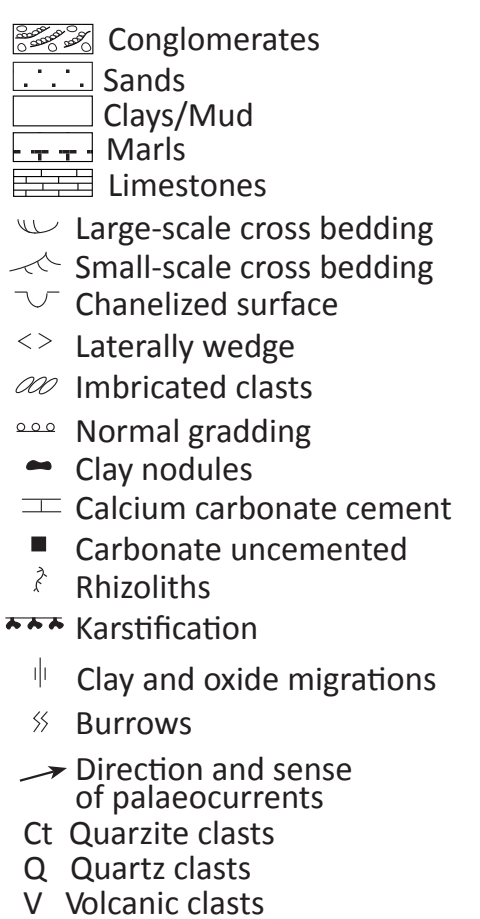
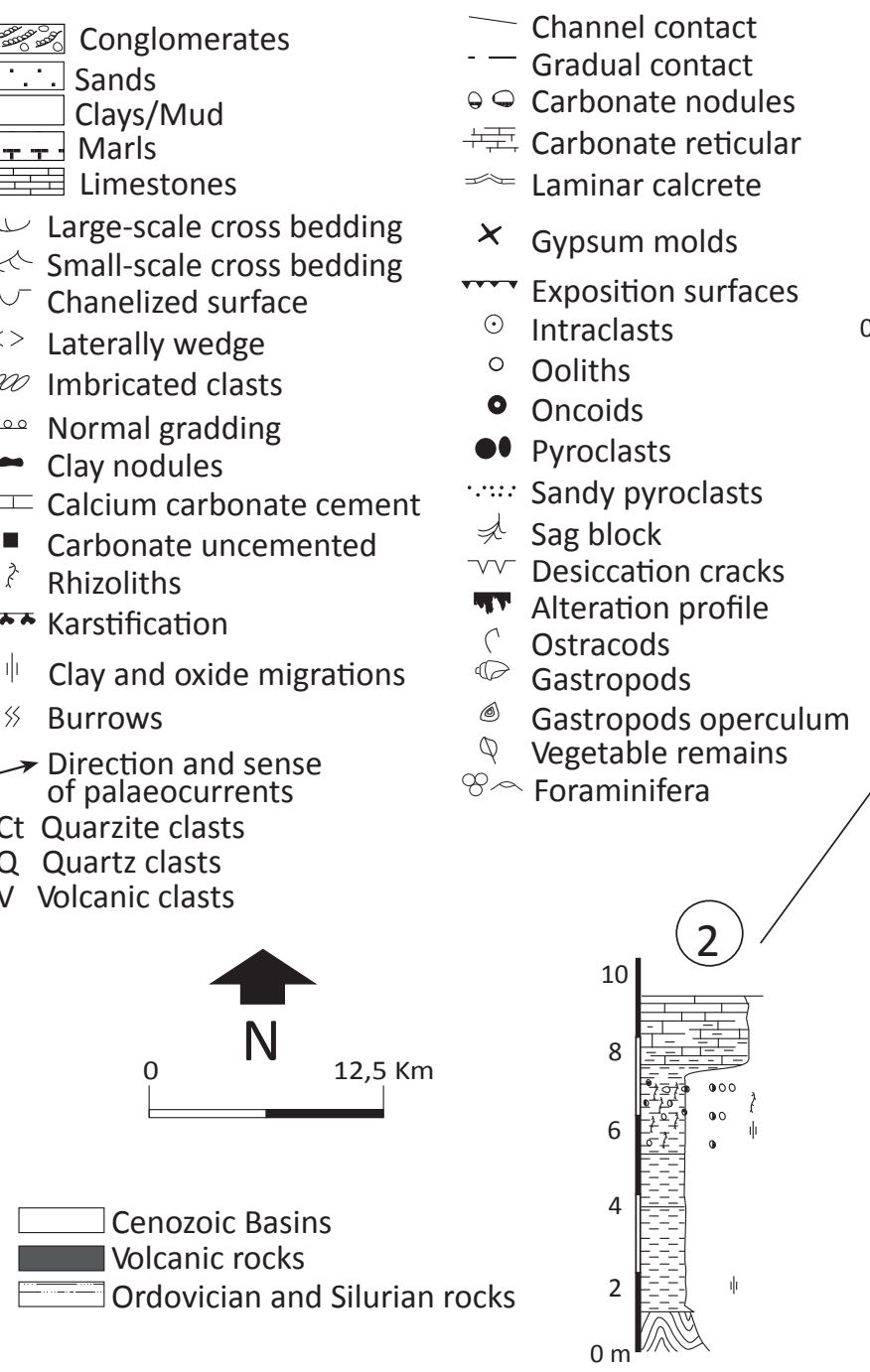

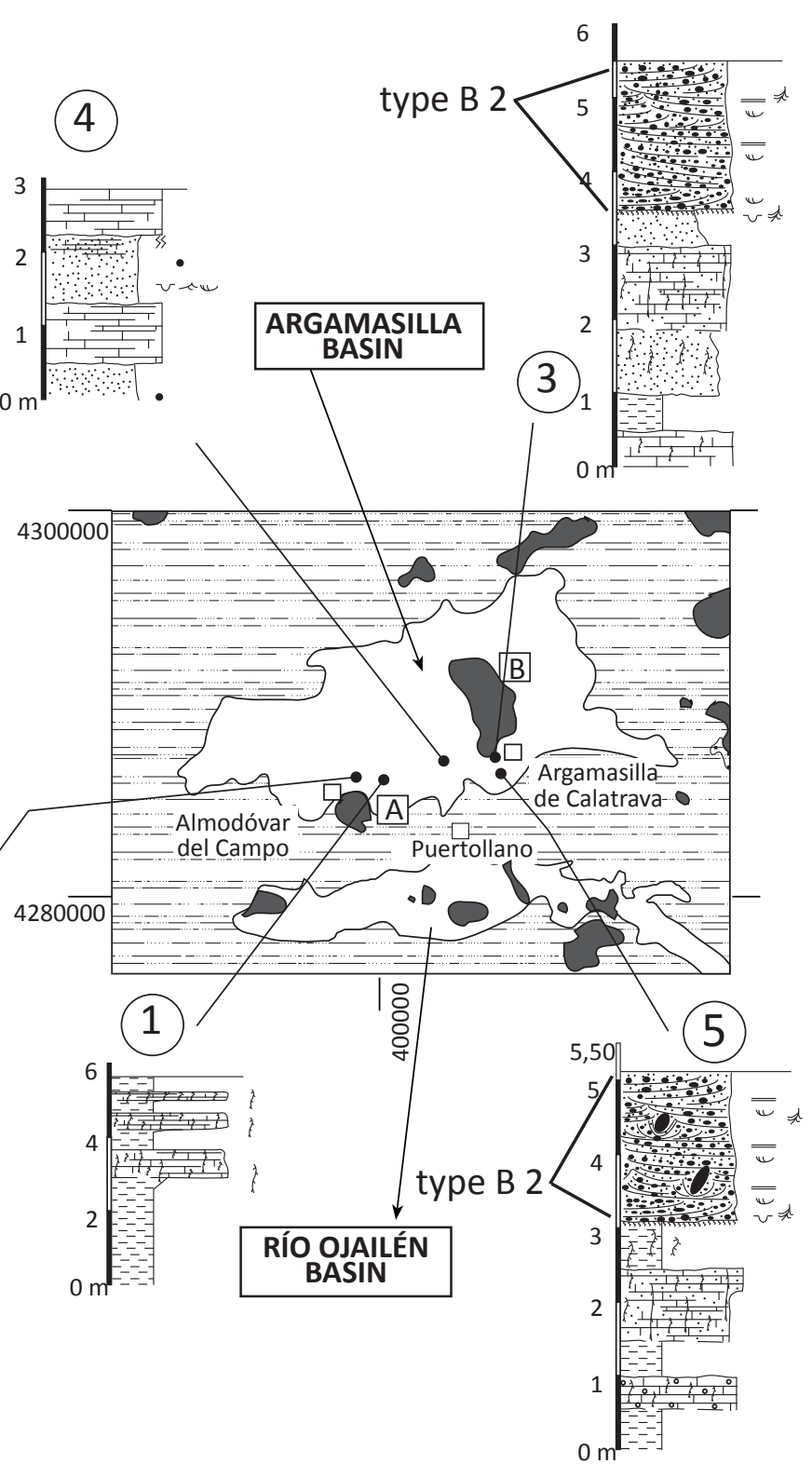

Fig. 3.- Stratigraphic sections of the Argamasilla Basin. A- Laguna Blanca maar and Cerro de Cabeza Parda volcano; B- Almodóvar del Campo maar. Fig. 3.- Columnas estratigráficas de la Cuenca de Argamasilla. A- Maar de la Laguna Blanca y volcán de Cerro de Cabeza Parda; B- Maar de Almodóvar del Campo.

clays show a polyhedral texture, relict bedding and fine root traces. This paleosoil has been dated by radiocarbon analysis yielding an age less than 7,000 BP (Middle Holocene) (González-Cárdenas et al., 2007 and 2008).

\section{Interpretation}

This volcaniclastic facies is inferred to be formed in a proximal setting around a small-volume volcano, as indicated by its coarse-grained nature, matrix pure texture and uncharacteristic grading, providing a massive nature to the deposits. These physical features, together with the composition and the shape of the pyroclasts suggest that this facies is dominated by the accumulation of fallout deposits, which were formed close to a vent in the rim surrounds the crater of a Strombolian style scoria cone (Fisher and Schmincke, 1984; Vespermann and Schmincke, 2000; Valentine et al., 2005). The disorganised lower part consisting of coarse breccia-like, together with the poor sorting and the absence of sedimentary structures also indicates proximity to the vent. It seems likely that pyroclasts were ejected following a ballistic trajectory during outbursts of hot and vesiculated magma from a vent that formed a ring around the vent and built a scoria cone. These deposits are inferred to be part of a flank of a scoria cone.

The material in the upper part has been weakly modified by pedogenesis and has the characteristics of a paleosoil (less than 7,000 years BP, dated by González-Cárdenas 
et al., 2007, 2008), indicating an interruption in volcanic activity.

This lithofacies is related to the well-preserved Columba Volcano (Fig. 8) whose volcanic edifice has a conical shape and a circular depression with a preserved crater. This edifice is composed of different stratigraphic episodes, indicating distinct eruptive episodes that began with lava-flows spreading out to the northeast and to the northwest in the base of the volcanic edifice. The Type A volcaniclastic deposits are mainly distributed to the southeast part, forming part of a Strombolian cone edifice from a pyroclastic succession. Some pedogenic textural modifications occurring in this lithofacies were used to dating the activity of Columba volcano, yielding an absolute age of 6,560 \pm 130 and 6,590 \pm 200 years B.P. (González-Cárdenas et al., 2007, 2008).

\subsection{Type B 1 volcaniclastic deposit (B1)}

This deposit occurs close to Calzada de Calatrava (Calzada-Moral Basin) being composed of a fining-upward sequence of several volcaniclastic lithofacies repeated over a thickness of several tens of metres (Fig. 9D). The base of this deposit is flat, sharp and erosive to centimetre scale. Materials show a decrease in grain size and an increase in fine materials towards the top.

The lower part consists of strongly consolidated breccia and coarse lapilli-tuff, with a matrix-supported texture of coarse tuff (Figs. 7C and D). These materials were very poorly sorted, containing clasts in subrounded and locally subangular shapes and a maximum diameter size of $20 \mathrm{~cm}$. The main clast components were juvenile and lithic (sandstones and shales). On average, the thickness of the lower part varies between 2 and $3 \mathrm{~m}$ and occupies a volume of $70-90 \%$ of the total. Internally, this part is massive, horizontally stratified or in tangential beds. They frequently show normal grading and rarely inverse grading.

This part grades upward into fine lapilli-tuff and coarsemedium tuff. Similarly, it comprises flat and parallel laminations (dunes and megaripples) with millimetre-thick cross-laminae, highlighted in most cases by variations in grain size. Paleocurrents are directed to the SE.

\section{Interpretation}

This type of deposit can be interpreted as a product of low density (dilute), highly turbulent pyroclastic surges that were generated in phreatomagmatic eruptions (Sparks and Walker, 1973; Sparks, 1976; Sheridan and Wohletz, 1981 and 1983; Fisher and Schmincke, 1984; Cas and Wright, 1987). The sedimentological characteristics, geometry and size of the sedimentary beds indicate

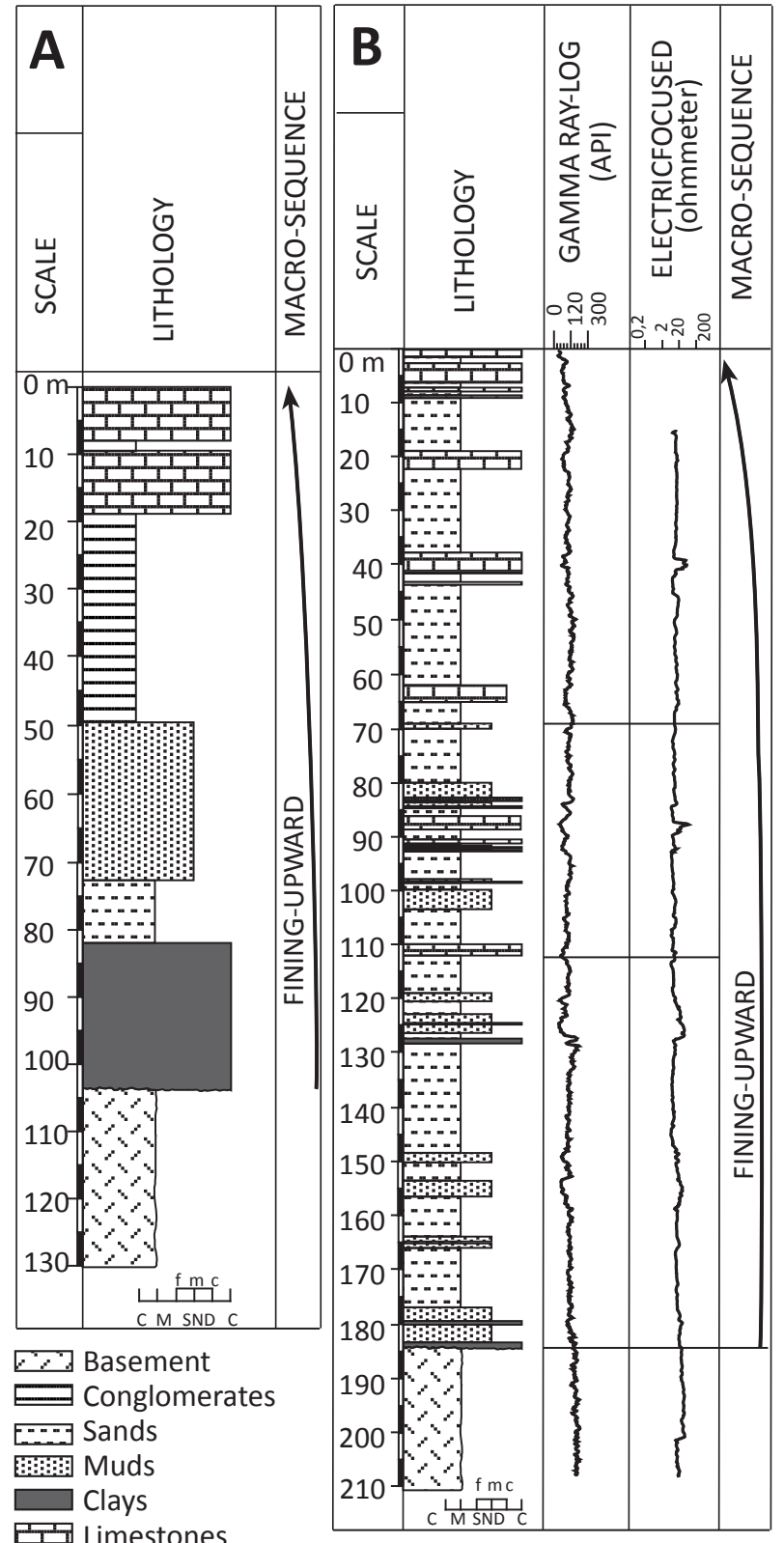

Fig. 4.- A) ARG-1 borehole drilled in the vicinity of Argamasilla de Calatrava. B) Main characteristics of the $8 / 11$ borehole drilled to the south of Aldea del Rey, modified after Rosales et al. (1988).

Fig. 4.- A) Sondeo ARG-1 perforado en los alrededores de Argamasilla de Calatrava. B) Principales características del sondeo 8/11 perforado al sur de Aldea del Rey, modificado a partir de datos de Rosales et al. (1988).

that a high-energy tractional flow deposited the base of the sequences. A decrease in tractional energy and flow speed occurred at the top of the sequence, as it is inferred by the decrease in the grain size, the transport of finer materials and a lesser amount of material.

B1 lithofacies features, namely, accretionary lapilli, oversteepened foresets and/or backsets, load structures and/or convolutions, and poor sorting are conclusive with a cool and moist deposit (less or equal to $100{ }^{\circ} \mathrm{C}$ ), in 


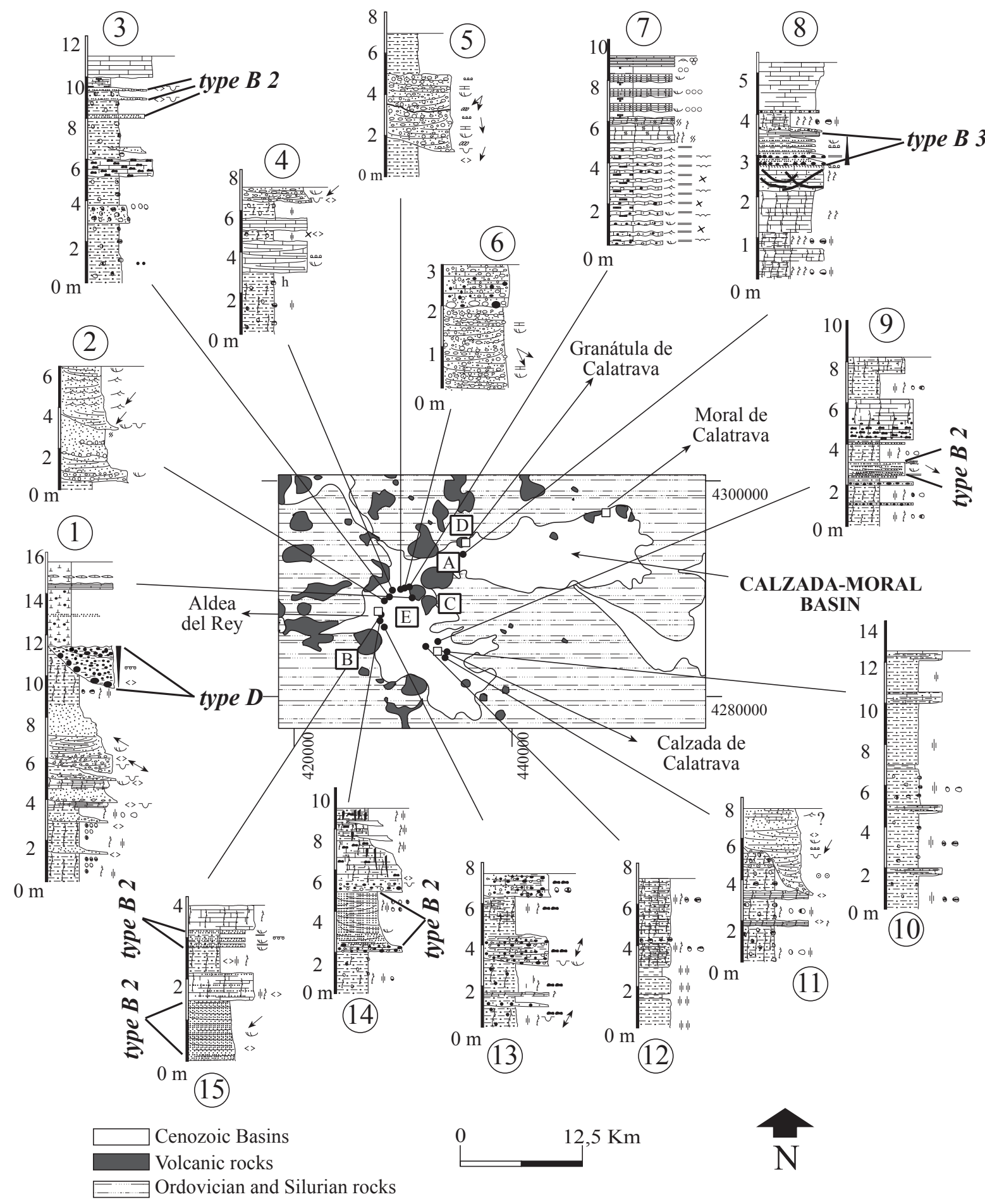

Fig. 5.- Stratigraphic profiles of the Calzada-Moral Basin. A- Columba volcano, B- El Cortijillo volcano, C- Cabezuelo volcano, DGranátula maar, and E-Casablanca maar.

Fig. 5.- Columnas estratigráficas de la Cuenca de Calzada-Moral. A- Volcán Columba; B- volcán El Cortijillo; C- volcán Cabezuelo; Dmaar de Granátula; E-maar de Casablanca.

agreement with Branney and Kokelaar (2002).

B1 deposit is vertically repeated (Fig. 9) and consists of successive pyroclastic single-surges showing a decrease in the grain size and an increase in fine materials at the top. It is inferred to be a medial-to-distal base surge suc- cession accumulated in the "ring-plain" around a maar or tuff ring volcano about several hundreds to few kilometres from their source. Bearing in mind the direction of the paleocurrents observed, this deposit is possibly related to the poorly preserved El Cortijillo Volcano. 


\begin{tabular}{|c|c|c|c|c|c|c|c|}
\hline \multicolumn{2}{|r|}{ TYPE OF DEPOSIT } & $\begin{array}{l}\text { SEDIMENTARY } \\
\text { STRUCTURES }\end{array}$ & COLOUR & $\begin{array}{c}\text { GEOMETRY } \\
\text { lateral extent / thickness }\end{array}$ & LIMIT & $\begin{array}{c}\text { OTHER } \\
\text { CHARACTERISTICS }\end{array}$ & INTERPRETATION \\
\hline $\mathbf{A}$ & & $\begin{array}{l}\text { disorganized, without } \\
\text { sedimentary structures }\end{array}$ & $\begin{array}{l}\text { dark brown and } \\
\text { black (5 YR 3/4) }\end{array}$ & $\begin{array}{c}\text { lenticular } \\
<300 \mathrm{~m} />7 \mathrm{~m}\end{array}$ & not visible & $\begin{array}{l}\text { Outsize bombs of up to } 1 \mathrm{~m} 3 \text { are } \\
\text { sometimes seen (Fig. } 7 \text { B). Calcium } \\
\text { carbonate coats the pyroclasts. }\end{array}$ & $\begin{array}{l}\text { Pyroclastic fall deposits } \\
\text { with ballistic projection } \\
\text { bombs }\end{array}$ \\
\hline B1 & 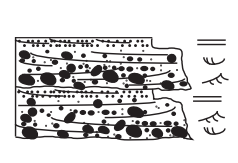 & $\begin{array}{l}\text { massive, horizontally } \\
\text { stratified, tangential } \\
\text { bedding, flat and parallel } \\
\text { laminations, dunes and } \\
\text { megaripples, } \\
\text { normal-graded } \\
\text { stratification. }\end{array}$ & $\begin{array}{l}\text { brown (5 YR 6/1) } \\
\text { ochre (10 YR 7/4) }\end{array}$ & $\begin{array}{c}\text { tabular } \\
>100 \mathrm{~m} /<3 \mathrm{~m}\end{array}$ & $\begin{array}{l}\text { flat, well } \\
\text { visible, and } \\
\text { small-scale } \\
\text { erosive }\end{array}$ & $\begin{array}{l}\text { The colours of the pyroclasts are of two } \\
\text { types: green and dark (10 GY } 5 / 2 \text { ), the } \\
\text { most frequent type, and light in colour } \\
\text { (N9), forming the minority. The directions } \\
\text { of the paleocurrents obtained reveal flows } \\
\text { towards the SE. Locally there may be veins } \\
\text { of calcium carbonate. }\end{array}$ & $\begin{array}{l}\text { Low-density (dilute) } \\
\text { pyroclastic surges with } \\
\text { decrease in tractional } \\
\text { energy in the upper } \\
\text { interval. }\end{array}$ \\
\hline B2 & 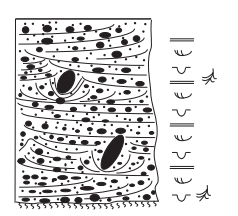 & $\begin{array}{l}\text { small to medium-scale } \\
\text { cross-bedding, dunes } \\
\text { and flat-parallel } \\
\text { lamination and sag } \\
\text { block }\end{array}$ & $\begin{array}{l}\text { blackish and } \\
\text { green (10 GY 5/ } \\
\text { 2), light in colour } \\
\text { (N 9). }\end{array}$ & $\begin{array}{l}\text { wedge } \\
>100 \mathrm{~m} / 0,45-3,00 \mathrm{~m}\end{array}$ & $\begin{array}{l}\text { planar, or } \\
\text { locally sharply } \\
\text { erosive }\end{array}$ & $\begin{array}{l}\text { The colours are green and light brown, } \\
\text { normally superimposed by a reddish } \\
\text { colour due to soil alteration. }\end{array}$ & $\begin{array}{l}\text { Low-density (dilute) } \\
\text { pyroclastic surges. } \\
\text { Fall of bombs with } \\
\text { ballistics projection. }\end{array}$ \\
\hline B3 & \begin{tabular}{l}
2 \\
\hdashline \\
\hdashline
\end{tabular} & $\begin{array}{l}\text { millimetre-thick parallel } \\
\text { lamination and normal } \\
\text { grading }\end{array}$ & $\begin{array}{l}\text { yellow } \\
\text { (10 YR 6/ 6) }\end{array}$ & $\begin{array}{l}\text { U-shaped channel } \\
<60 \mathrm{~m} / 4 \mathrm{~m}\end{array}$ & $\begin{array}{l}\text { erosive, } \\
\text { channelized }\end{array}$ & $\begin{array}{l}\text { The direction and sense of the } \\
\text { paleocurrents provided by this } \\
\text { channel is } \mathrm{N} 30^{\circ} \text {. }\end{array}$ & $\begin{array}{l}\text { Low-density (dilute) } \\
\text { pyroclastic surges } \\
\text { with high flow } \\
\text { regime. }\end{array}$ \\
\hline B4 & 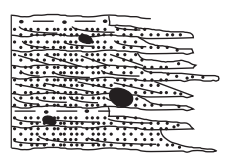 & $\begin{array}{l}\text { parallel lamination, } \\
\text { dunes and ripple } \\
\text { cross-lamination, } \\
\text { massive or with a } \\
\text { horizontal lamination }\end{array}$ & $\begin{array}{l}\text { brown (10 YR 7/4) } \\
\text { to (5 YR 3/2) }\end{array}$ & $\begin{array}{c}\text { tabular } \\
>100 \mathrm{~m} / 5-25 \mathrm{~cm}\end{array}$ & $\begin{array}{l}\text { irregular and } \\
\text { slightly } \\
\text { erosive }\end{array}$ & $\begin{array}{l}\text { The laminations are highlighted by } \\
\text { variations in grain size and colour. }\end{array}$ & $\begin{array}{l}\text { Low-density (dilute) } \\
\text { pyroclastic surges. Air } \\
\text { fall deposits in the upper } \\
\text { interval. }\end{array}$ \\
\hline C & 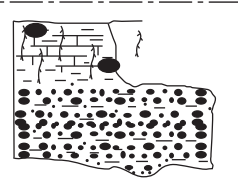 & $\begin{array}{l}\text { normal grading with a } \\
\text { massive base or with } \\
\text { horizontal stratification. }\end{array}$ & $\begin{array}{l}\text { reddish brown (5 YR } \\
5 / 6 \text { to } 10 \text { R } 4 / 6 \text { ) }\end{array}$ & $\begin{array}{l}\text { lenticular, channelized } \\
<50 \mathrm{~m} / \text { various } \mathrm{m}\end{array}$ & $\begin{array}{l}\text { erosive at } \\
\text { metric scale, } \\
\text { and is } \\
\text { somewhat } \\
\text { channelized }\end{array}$ & $\begin{array}{l}\text { The shape of the clasts is subrounded and } \\
\text { the more angular ones have worn sides. }\end{array}$ & $\begin{array}{l}\text { Secondary volcanic } \\
\text { sediments were } \\
\text { reworked by fluvial } \\
\text { streams. }\end{array}$ \\
\hline D & 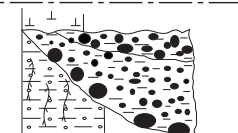 & $\begin{array}{l}\text { both intervals show } \\
\text { inverse grading }\end{array}$ & $\begin{array}{l}\text { lower red interval } \\
\text { (10 R 4/ 6) and a } \\
\text { green upper } \\
\text { interval (5 Y } 6 / 4 \\
\text { to } 10 \text { Y } 6 / 2 \text { ). }\end{array}$ & $\begin{array}{c}\text { lenticular } \\
<3 \mathrm{~m} /<10 \mathrm{~m}\end{array}$ & $\begin{array}{l}\text { planar, or } \\
\text { locally sharply } \\
\text { erosive }\end{array}$ & $\begin{array}{l}\text { Deposits interbeded between lacustrine } \\
\text { marls and limestones and fluvial red } \\
\text { siltstones and clays }\end{array}$ & $\begin{array}{l}\text { Deposits of } \\
\text { scoria/spatter cones }\end{array}$ \\
\hline
\end{tabular}

Table 1.- Description of the volcaniclastic deposits.

Tabla 1.- Descripción de los depósitos volcanoclásticos.

\subsection{Type B 2 volcaniclastic deposit (B2)}

This type of volcaniclastic lithofacies occurs interbedded between terrigenous materials (profiles 3 and 5 in Fig. 3 and profiles 3, 9, 14 and 15 in Fig. 5) and is widely represented in the Argamasilla and Calzada-Moral basins. This volcaniclastic deposit is composed of a centimetrethick alternation of coarse- to medium-grained lapilli to coarse- to medium-grained ashes (Table 1) with a finingand thinning-upwards sequence with thickness between 0.45 and 3.00 metres (Figs. $7 \mathrm{E}$ and F). Frequently, it presents a wedge geometry pinching out laterally. The base is planar or sharply erosive and occasionally displays an ash-coloured bed (grey) almost $30 \mathrm{~cm}$ thick. The deposit is matrix-supported with a predominance of juvenile over lithic fragments. The colours of the lithofacies are green and light brown, normally superimposed by a reddish colour. They are well sorted and show sub-rounded to rounded, sometimes subangular, shapes.
The Type B 2 volcaniclastic deposit contains sedimentary structures including small to medium-scale crossbedding, with troughs up to $4 \mathrm{~m}$ amplitude and heights up to $1 \mathrm{~m}$. Frequently, the bedforms show an asymmetric geometry (Fig. 7 E) where the sets show a sigmoidal aspect with truncated low-angle laminae. These structures may also show dunes and flat-parallel lamination, with millimetre-thick laminae, where normal grading is not uncommon. Likewise, low-angle laminae with a leaning opposite to the flow direction occur, in a similar way to the antidunes of fluvial environments.

Lithic fragments (mainly palaeozoic sandstones), bombs and blocks up to $30 \mathrm{~cm}$ in size often break the stratification (Fig. 7 F) forming bomb sags. This structure is emplaced ballistically into deformable materials and it is mainly found in alternating beds of fine-grained ash and lapilli, causing a depression with deranged laminae. 
B2 deposit has a very broad distribution in these sedimentary basins. It was observed in profiles 3 and 6 in the Argamasilla Basin (Fig. 3). Flow directions measured in sedimentary structures and in deformation tails left by the sag block structures $\left(\mathrm{N} 10^{\circ} \mathrm{E}\right)$ are coincident, pointing to the same source, namely, Laguna Blanca Maar and Cabeza Parda Volcano.

B2 deposits were also identified in profiles 13, 14 and 15 in the proximities of Aldea del Rey in the CalzadaMoral Basin (Fig. 5). Their sources could be some of the vents identified in the neighbourhood. This kind of deposit was also observed in the vertical profile number 9 at Calzada de Calatrava (Fig. 5), where paleocurrents measured point to the El Cortijillo Volcano. Finally, in the vertical profile number 8 , close to Granátula de $\mathrm{Ca}$ latrava (Fig. 5), this type of deposit reaches a thickness of less than $1.00 \mathrm{~m}$, and the best candidate for the source, due to its proximity, is the Granátula Maar.

\section{Interpretation}

The abundance of current structures, well-developed bedding, fining and thinning-upwards sequences, wellsorted particles and small to medium-scale cross-bedding in these deposits is evidence of a pyroclastic density current (base surge) (Fisher and Schmincke 1994; Walker, 1983; Carey, 1991; Druitt, 1998). So, this lithofacies was formed as a consequence of a turbulent and low-density pyroclastic density current such as base surges (Sparks and Walker, 1973; Cole, 1991 and Dellino et al., 2004 a and b). Facies sequences and deposit structures suggest that these pyroclastic base surges had a phreatomagmatic explosive origin from a nearby maar or tuff ring (see Fisher and Schmincke, 1984; Cas and Wright, 1987).

The occurrence of bomb sags (impact structures) distorting the previously deposited materials indicates that the deposit is located close to the vent and represents a strong evidence of a contemporaneous explosive and subaerial volcanism that influenced the intra-continental fluvio-lacustrine sedimentation in the basin.

\subsection{Type B 3 volcaniclastic deposit (B3)}

This volcaniclastic deposit has been only observed in Granátula de Calatrava (Calzada-Moral Basin, Fig. 6). This lithofacies shows channel geometry, with a lateral extension up to $60 \mathrm{~m}$ and a maximum thickness of $4 \mathrm{~m}$. The paleocurrent directions provided by this channel are $\mathrm{N} 30^{\circ}$. The above mentioned A deposit is underlying B3, as it can be observed in the eastern side of the Columba Volcano (Fig. 8).

B3 is composed of fining -upwards sequences of fineto medium-grained lapilli-tuff, changing to fine- to me-

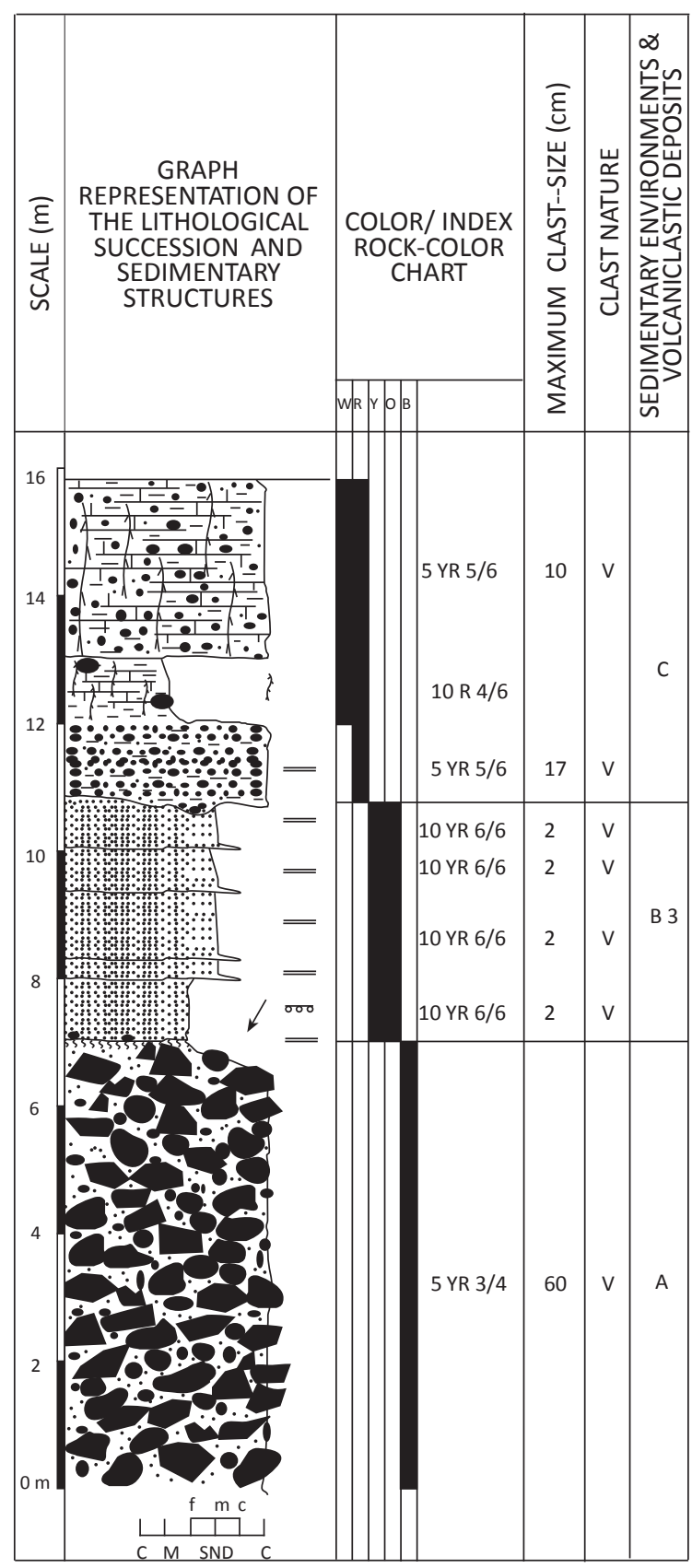

Fig. 6.- Stratigraphic section close to the Columba volcano in the Calzada-Moral Basin.

Fig. 6.- Columna estratigráfica cerca del volcán Columba en la Cuenca de Calzada-Moral.

dium-grained tuffs at the top. Both intervals are strongly lithified and finely stratified in beds of less than 15 centimetres thick and yellowish in colour (Figs. $10 \mathrm{~A}$ and B). Occasionally, the base of the deposit contains bombs with sizes up to $15 \mathrm{~cm}$, that could correspond to the A deposit subsequently re-incorporated into B3. In this latter case, the sedimentary structures were readapted. Clasts in B3 are commonly primary juvenile. The particle shapes are from subrounded to strongly rounded, very homogeneous and well sorted. 
Internally, the lower and upper parts of these sequences display a millimetre-thick parallel lamination and normal grading (Fig. $10 \mathrm{~B}$ ).

\section{Interpretation}

The well-developed parallel lamination of B3 is interpreted to be a traction deposit from a high-flow regime. This kind of deposits is consequence of low-density pyroclastic surges generated by energetic explosive phreatomagmatic eruptions (Wohletz and Sheridan, 1979; Sheridan and Wohletz, 1981 and 1983; Cas and Wright, 1987; Cole, 1991; Wohletz, 1993, 1998).

Moreover, the vertical and lateral relationships between both intervals of the sequence indicate turbulent conditions together with transportation in upper and lower flow-regime conditions. The bedding with centimetrescale fining-upwards sequences and the well-sorted texture indicate warm and dry surges (cf. Fisher and Schmincke 1994; and Walker, 1983).

\subsection{Type B 4 volcaniclastic deposit (B4)}

This deposit is composed of a variety of lithofacies outcropping near Calzada de Calatrava (Calzada-Moral Basin) (Fig. 9). It comprises fining-upward sequences of tuff beds of 5 to $25 \mathrm{~cm}$ thick (Figs. $10 \mathrm{C}$ and D). Estimates of volcaniclastic fragment sizes indicate that these sequences grade from fine- to medium-grained lapilli-tuff to coarse- to medium-grained ash. The lower limit of the sequences is well-defined, irregular and slightly erosive. The deposit shows tabular bedding and the individual beds predominantly consist of juvenile fragments.

The basal beds are up to $20 \mathrm{~cm}$ thick. They are strongly lithified, brown in colour and internally contain a variety of primary sedimentary structures, such as parallel lamination, dunes and ripple cross-lamination, and other very extended laminations indicating paleocurrents coming from the S and SE. The layer displays scattered and isolated lithic fragments of pyroclasts up to $15 \mathrm{~cm}$.

The upper interval of the sequence is light brown in colour, with thickness up to $5 \mathrm{~cm}$ and appears to be unconsolidated. It is massive or with a horizontal lamination, highlighted by variations in grain size and colour (Figs. $10 \mathrm{C}$ and D).

\section{Interpretation}

Paleocurrent directions allowed the provenance of B4 to be established (i.e., El Cortijillo Volcano, CalzadaMoral Basin).

The fine- to very fine-grained size together with some sedimentary structures occurring at the base indicate a low-speed tractional flow. All these features are in line with low-velocity, dilute and turbulent phreatomagmatic surges, similar to those of B2. Textural differences between this lithofacies and other similar ones were interpreted in terms of different sources, variations in fragmentation styles and geographical location in relation with their source areas (e.g., proximal to distal facies).

The horizontal mantle bedding lamination of the upper part of B4 is clearly a separate facies and was interpreted as a pyroclastic-air fall deposit (see: Walker 1983; Cas and Wright 1987).

Occasionally, recurrences of fining-upward and cyclic sequences were found (Fig. 9), which are typical for a succession composed of deposits accumulating formed from pyroclastic surges and intermittent pyroclastic airfall events. Such superposition of processes in vertical can occur in short periods of time (days to weeks) and can be considered geologically instantaneous. This succession is considered proximal to its volcanic source area (e.g., to the poorly preserved El Cortijillo Volcano).

\subsection{Type $C$ volcaniclastic deposit (C)}

This deposit has only been observed in Granátula de Calatrava (Calzada-Moral Basin) (Fig. 6). The base of this lithofacies is erosive at the metre scale and is somewhat channelized over B3 (Fig. 10 F).

At the base, it comprises particles larger than $2 \mathrm{~cm}$ (pebble-boulder conglomerate and breccias) and a clastsupported texture. Maximum grain size is $17 \mathrm{~cm}$, with a main of 4-8 cm. The deposit is reddish brown in colour, with clasts of olivine basalt $(90 \%)$ and volcaniclastic clasts, e.g., pieces of tuff or lapilli tuff (10\%). (Figs. $10 \mathrm{E}$ and F). The matrix consists of coarse-grained ashes and fine-grained lapillis with a superimposed weak cementation of calcium carbonate rimming pyroclasts. Deposits show a poor sorting at the base and it is well sorted at the top (Fig. 10 E). Pyroclasts are subrounded in shape and the most angular show abraded margins.

The deposit exhibits normal grading, massive stratification at the base and a diffuse horizontal stratification at the top. Laterally, it has an extent of 75-100 $\mathrm{m}$ and a few metres thick.

Towards the top, the deposit passes gradually to red terrigenous clays (10 R 4/6) with cementation of calcium carbonate, a low content in fine-grained sands and abundant pedogenic modifications, such as carbonate root traces and clay and carbonate migrations.

\section{Interpretation}

The composition of clasts suggests diverse sources from eroded lavas and volcaniclastic materials. Sedimentological characteristics indicate that transportation pre- 
ceded the deposition, supporting a resedimented volcaniclastic deposit with a secondary origin.

The secondary origin of the Type $\mathrm{C}$ deposit can be explained in terms of two contrasting scenarios, namely, eruptive and sedimentation. Regarding the former, the deposit could have been formed when rain soaks loose finegrained volcanic material in the proximities of volcano, probably on its lower outer flank. In this sense, sedimentary processes would be similar to rain-triggered lahars, which would mean no direct volcanic activity involved in their formation; however, the rain-triggered lahars must have been initiated shortly after the eruptions ceased (e.g. having barren, loose tephra on the surface without vegetation cover or soil). These pyroclastic materials could became remobilized and began to flow downhill, being subsequently accumulated in the intra-volcanic flat, in low lying regions similar to those modelled around stratovolcanoes on their ring-plains (e.g., Manville et al., 2009) or on vegetation free ash plains of volcanic complexes such as Ambrym in Vanuatu (e.g., Németh et al., 2009). Remobilization of wet tephra on a tuff ring crater rim is a well-documented process and can produce extensive gully networks that eventually able to feed major sediment channels and to redistribute tephra toward the flank of the tuff ring (e.g., Németh and Cronin, 2007).

Moreover, the occurrence of some stratification and normal grading in the $\mathrm{C}$ deposit studied rules out proximal debris flows, and is more in line with a hyperconcentrated flow deposit subsequently accumulated in the intra-tuff ring/scoria cone plains. The location of these hyperconcentrated flow deposits is likely coincident with major artery systems, as convey belts of transporting pyroclasts from monogenetic volcanoes to the normal terrestrial sedimentary basin (e.g., Manville et al., 2009).

The secondary origin can also be caused by volcaniclastic fluvial processes, or a simple washout of pyroclasts. Pyroclast shape and clast rounding are in line with a water-supported transport. Similarly, sorting and sedimentary structure evolution evidence fluvial transport and reworking of volcaniclastic materials, the sedimentary processes being, therefore, similar to those of fluvial environments (see McGowen and Groat, 1971; Eynon and Walker, 1974; or Miall, 1977, 1978 and 1992). Hence, it seems likely that the material was transported as bed load and deposited in form of longitudinal bars in braided fluvial channels.

The Columba Volcano is the best candidate for $\mathrm{C}$ lithofacies source, as it is inferred from the fact that this facies is extra-caldera and very close to Columba Volcano (less than $1.5 \mathrm{~km}$ ) and it is located in the footslope of the volcano. These features, together with the grain size, well sorting, shape and rounding pyroclasts, suggest a origin related with transitional hyperconcentrated flows and dilute fluvial processes. These deposits would be typically remobilised by hyperconcentrated flows that can end up in a sediment-overcharged fluvial network (at least in their proximal area).

Fig. 7.- (next page) (A) Type A volcaniclastic deposit showing a disorganised and massive texture. In the upper part the limit with the Type B3 can be seen. The circle includes a hammer for scale. (B) Type A volcaniclastic deposit showing a massive and disorganized texture of lapilli, blocks and bombs of a mean grain size between 20 and $25 \mathrm{~cm}$ and basaltic composition. (C) Type B1 volcaniclastic deposit showing fining-upwards sequences at the bottom, strongly consolidated breccia and coarse lapilli-tuff (dark colours) with a matrix-supported texture, cross-bedding and horizontal stratification. Fine lapilli-tuff and coarse-medium tuff with horizontally lamination (clear colours) are shown in the upper part. Strata with inverse and vertical dips. (D) Detail of type B1 volcaniclastic deposit showing centimetre sequences with scour surfaces between cross-bedding and horizontal lamination. Strata present inverse grading, vertical dips and calcite veins. (E) Type B2 volcaniclastic deposit with beds ranging from coarse-medium lapilli to coarse-medium ashes. Asymmetrical bedforms with trough cross-bedding and asymptotic laminae with the bottom. The flow direction is towards the right. At the top, alternation of coarse-medium lapilli (dark colours) and coarse-medium ashes (clear colours) with horizontal stratification and lamination. The arrows point to several bombs in the deposits. (F) Sag-block deformation structure within the type B2 volcaniclastic deposit. Sequences of coarse-medium lapilli and coarse-medium ashes in centimetre-thick layers with horizontal stratification that were distorted when the bomb fell (ballistic trajectory indicates transportation from right to left on the image).

Fig. 7.- (página siguiente) (A) Depósito volcanoclástico tipo A con textura desorganizada y masiva. En la parte superior se observa el límite con los depósitos volcanoclásticos tipo B3. En el círculo hay un martillo de escala. (B) Depósito volcanoclástico tipo A con una textura desorganizada y masiva de lapilli, bloques y bombas de un tamaño medio entre 20 y $25 \mathrm{~cm}$ y composición basáltica. (C) Depósito volcanoclástico tipo B1: secuencias granodecrecientes que en la parte inferior presentan brechas fuertemente consolidadas y lapillis tobáceos gruesos (colores oscuros), con una textura matriz soportada y con estratificación cruzada y estratificación horizontal. En la parte superior, lapillis tobáceos finos y tobas gruesas-medianas con laminación horizontal (colores claros). Estratos con buzamiento inverso y vertical. (D) Detalle del depósito volcanoclástico tipo B1 con secuencias centimétricas con superficies erosivas y estratificación cruzada y laminación horizontal. Estratos con buzamiento inverso y vertical y abundantes venas de calcita. (E) Depósito volcanoclástico tipo B2 con secuencias granodecrecientes de lapilli grueso-medio y cenizas gruesas-medias. Morfologías de fondo asimétricas y con estratificación cruzada en surco y láminas asintóticas con la parte inferior. La dirección de flujo es hacia la derecha. En la parte superior, alternancia de lapillis gruesos-medianos (colores oscuros) y cenizas gruesas-medianas (colores claros) con estratificación y laminación horizontal. Las flechas apuntan a varias bombas en el depósito. (F) Estructura de deformación tipo "sag-block" dentro del depósito volcanoclástico tipo B2. Secuencias de lapillis gruesos-medianos y cenizas gruesas-medianas en capas de espesor centimétrico con estratificación horizontal que fueron distorsionadas cuando cayó la bomba (la trayectoria balística indica transporte desde la derecha hacia la izquierda en la imagen) 


\subsection{Type D volcaniclastic deposit (D)}

This deposit has a local distribution in the sedimentary basins analysed. Near Aldea del Rey in the CalzadaMoral Basin this deposit partly filled the bottom of the Casablanca Maar (Vega de Castellanos) (Fig. 8).

The stratigraphic context of this volcaniclastic deposit is important for understand its formation. The Casablanca Maar is a circular depression 1-2 km across, where two sedimentary units were differentiated (basal unit and upper unit; profile 1, Fig. 5). The predate sediments of the basal unit comprise sandy siltstones and clays, sands and some conglomerate beds. The latters represent sedimentation in braided fluvial channels with gravel bars and sandy megaripples. Sandy siltstones and clays represent sedimentation in a flood plain.

The base of maar depression is an erosive surface with several metres of relief carved in sediments of the basal unit. This surface corresponds to an angular unconformity with a small difference of angle of dipping (less than $15^{\circ}$ towards the centre of the depression) between the layers of the units.
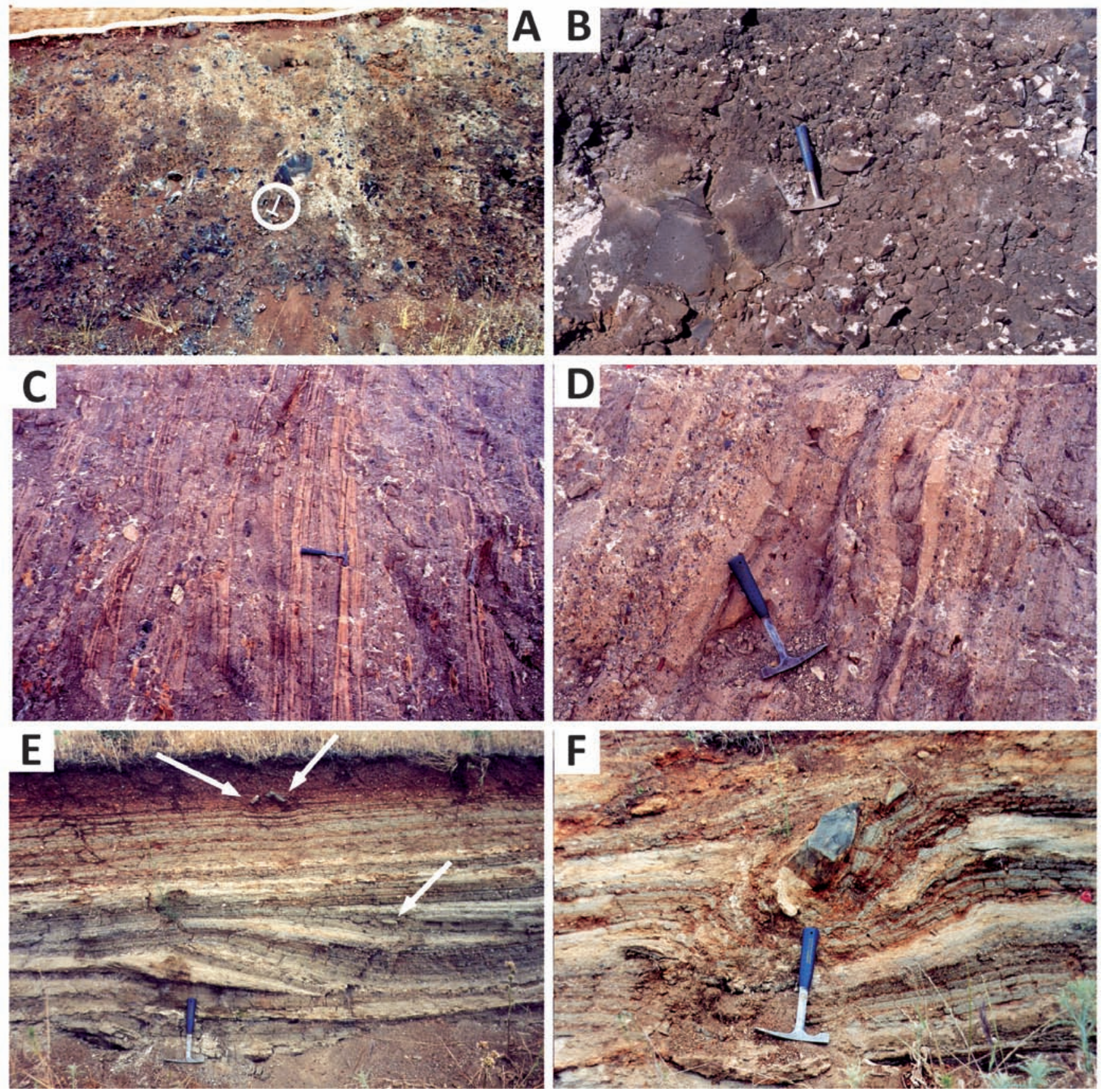

Fig. 7.- Caption in previous page.

Fig. 7.- Pié de figura en la página previa. 


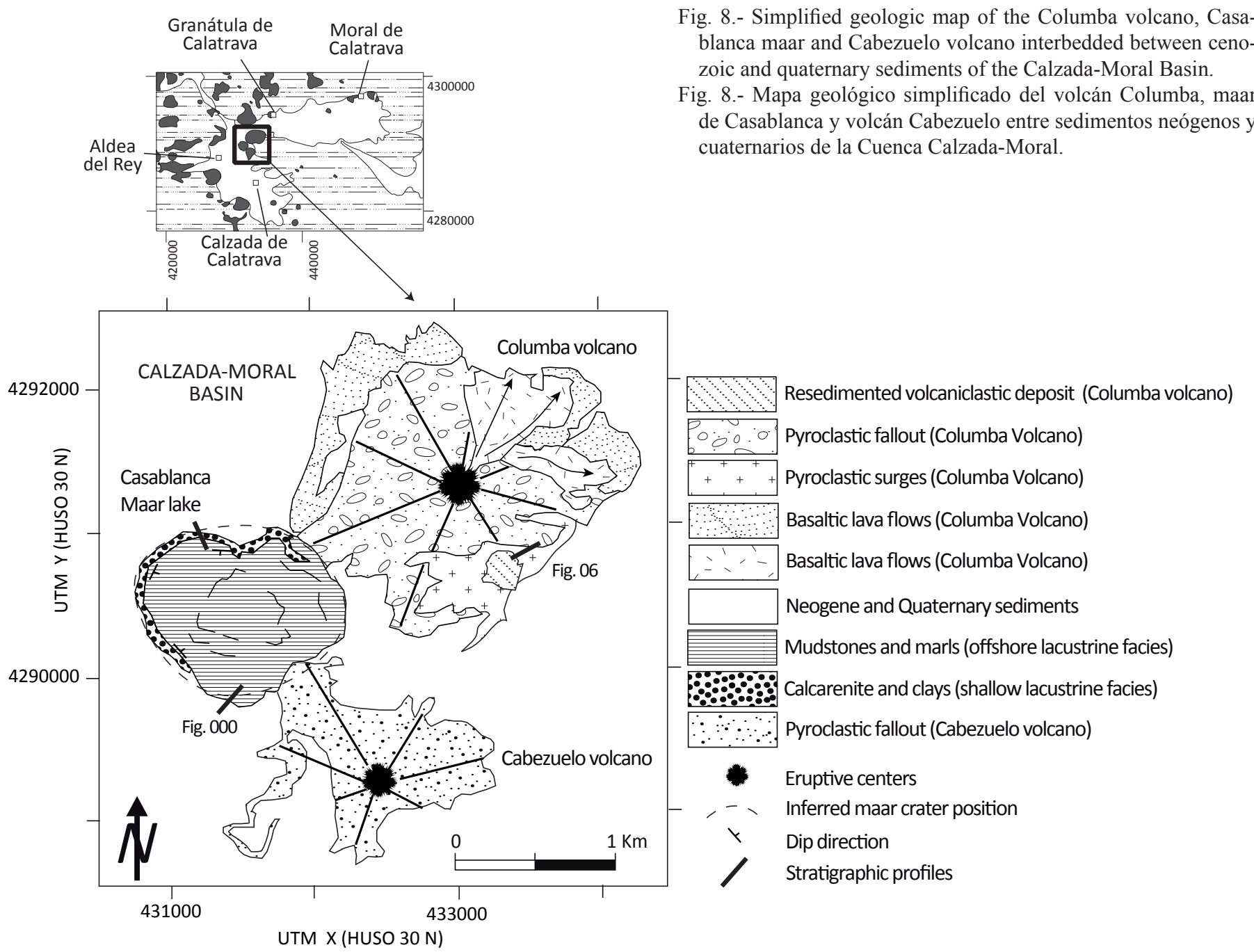

Type D volcaniclastic deposit occurs in the upper unit. Its thickness is around $3 \mathrm{~m}$ but a lateral thinning was observed towards the edge of the depression. In the lower part and over the angular unconformity, subrounded bombs and blocks up to $50 \mathrm{~cm}$ in diameter are concentrated at the base of this deposit and embedded in the matrix (Fig. 11A). These bombs and blocks can be followed cartographically around a narrow marginal zone of the depression (maar).

Type D lithofacies is formed by well-sorted coarseto-very coarse-grained lapilli, in a matrix of medium-to coarse-grained ash (Fig. 11 B). It shows a red in colour interval in the lower part, changing to green in the upper part. In this deposit, tractional sedimentary structures are lacking and only inverse grading in the internal organisation was observed.

Finally, the sediments of the upper unit reach a maximum thickness of $15 \mathrm{~m}$ (profiles 1 and 7, Fig. 5) and include calcarenites, marls and limestones with scattered and altered pumite fragments (up to $2 \mathrm{~cm}$ ). These sediments exhibit a dip towards the centre of the depression.

\section{Interpretation}

The ancient Casablanca Maar has a small basin formed during a maar-forming eruption. Around and outside of this depression non-volcaniclastic deposits have been found (Fig. 8) and were correlated with non-volcaniclastic terrestrial sediments described in the Calzada-Moral Basin (Profile 1, Fig. 5).

The occurrence of subrounded bombs and blocks up to $50 \mathrm{~cm}$ in diameter at the basal surface of Type D deposit, together with its location above the angular unconformity suggest that the basal unit is not part of the maar depression filling deposits. It seems likely that a fluvial network breached the maar, establishing through the shallow and flat maar basin. It should promote the development of a lake that partially or fully filled the maar, providing an extensive lacustrine sedimentary cover over the entire maar basin.

Similarly, the absence of impact craters by ballistic bombs allows interpret the occurrence of volcanic bombs and blocks appearing at the base of this volcaniclastic deposit as rolling large bombs from the inner crater wall of 

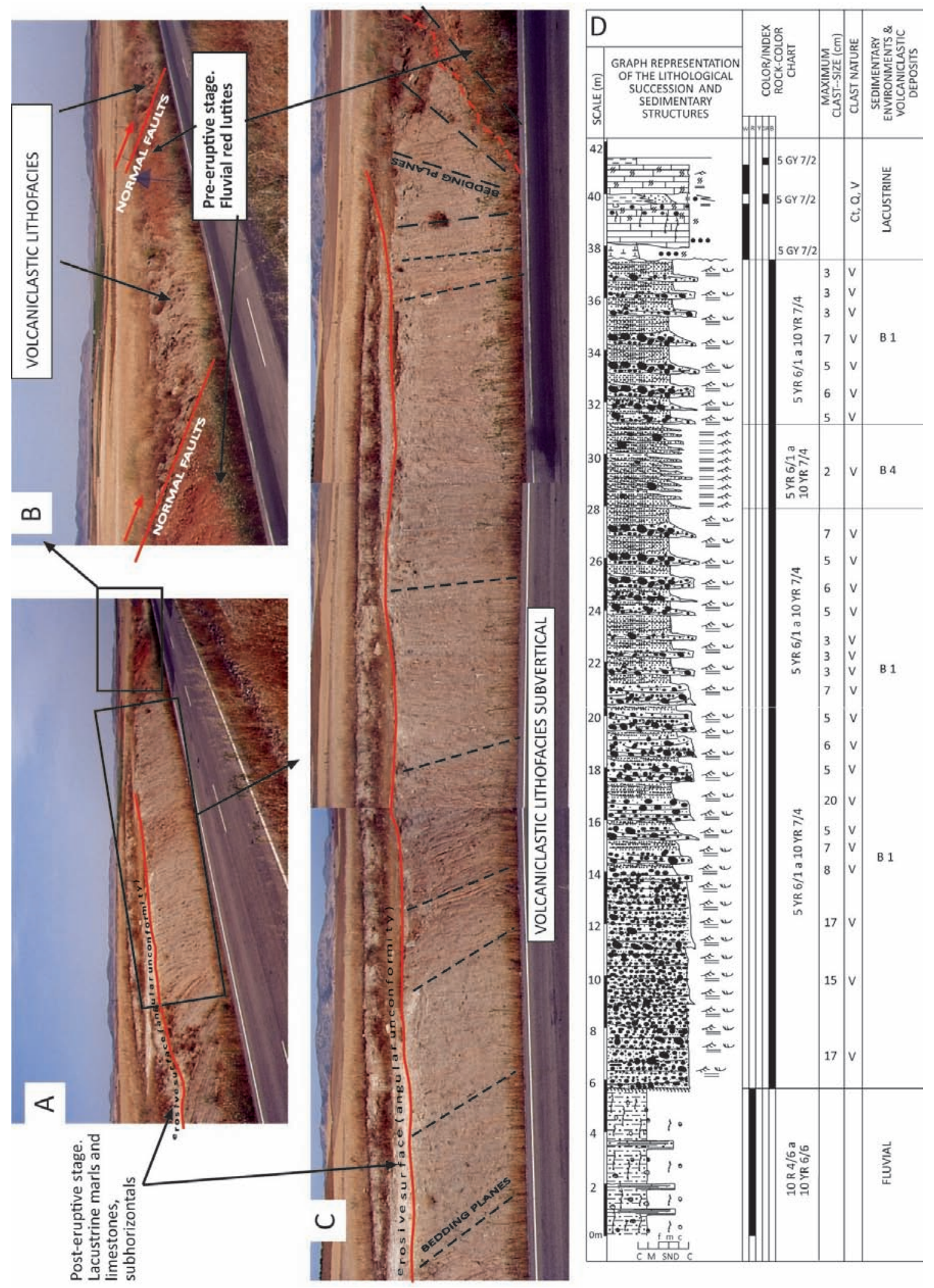

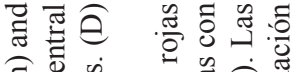

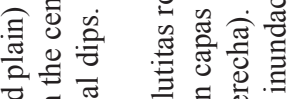

응

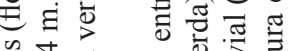

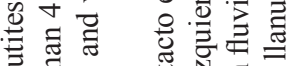

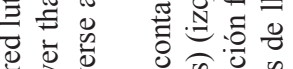

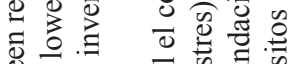

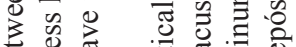

过

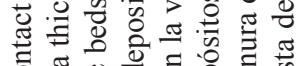

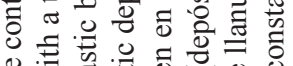

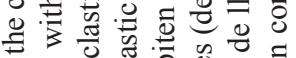

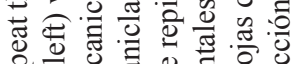

눈

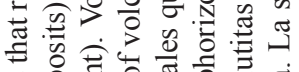

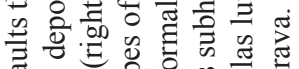

要

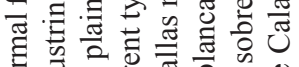

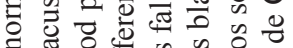

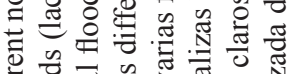

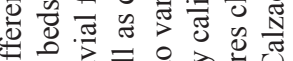

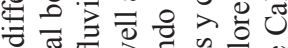

on

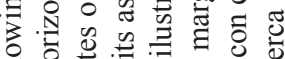

응

品

西. 政

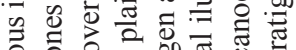

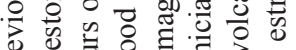

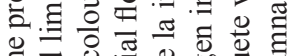

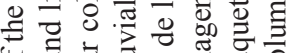

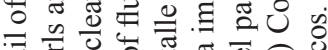

胥

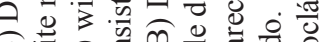

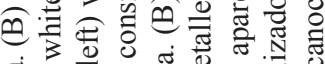

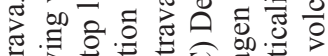

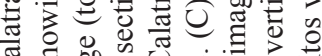

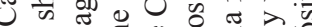

응

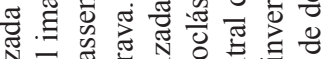

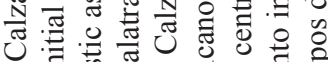

:

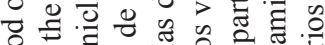

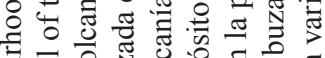

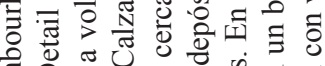

管

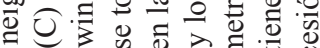

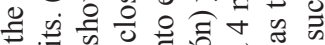

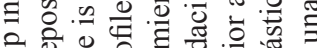

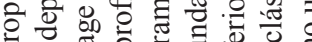

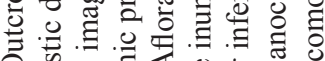

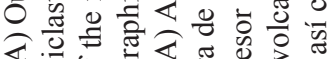

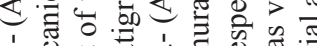

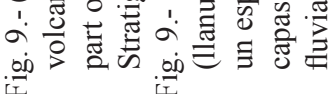



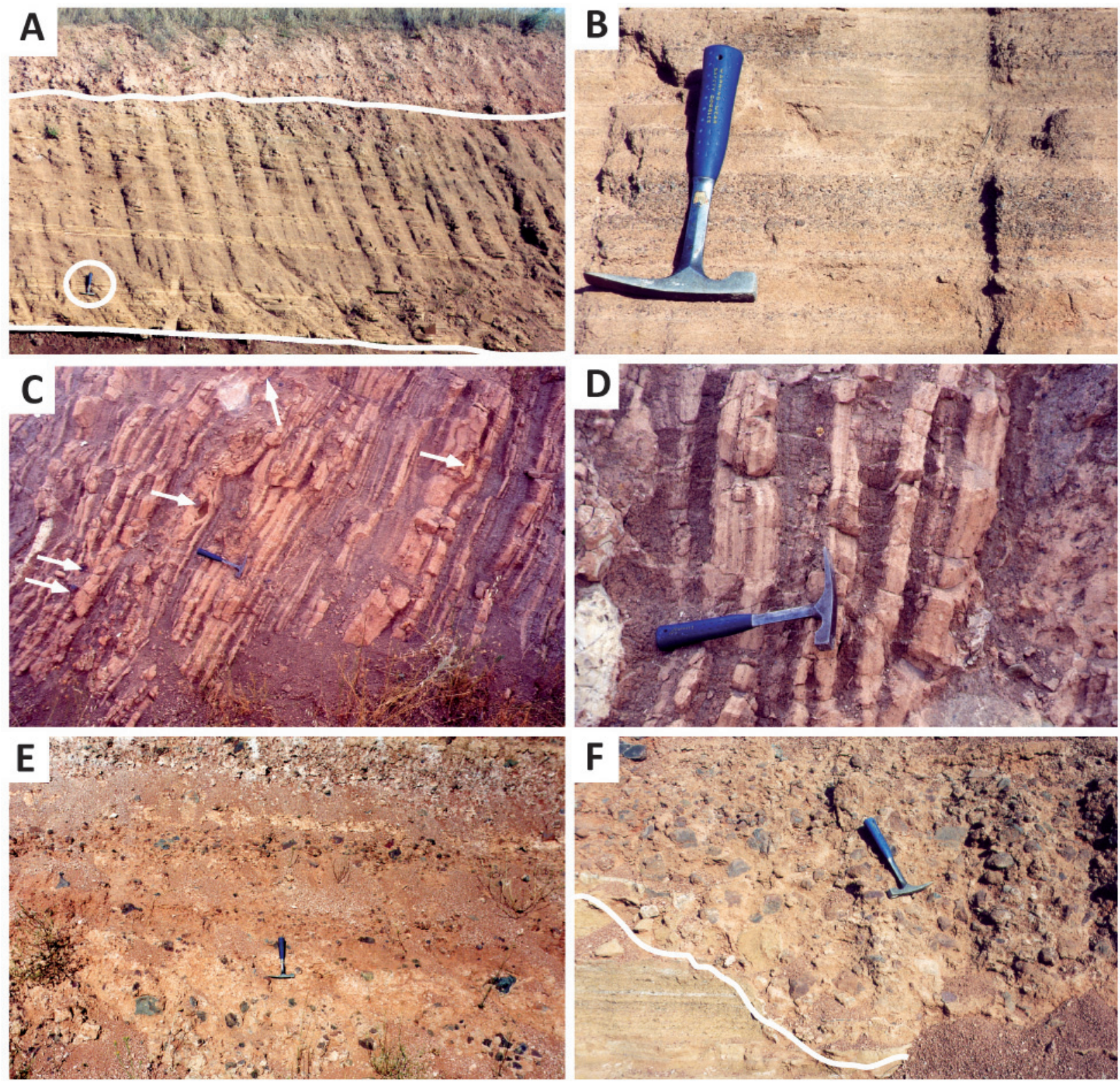

Fig. 10.- (A) Type B3 volcaniclastic deposit. In this image fining-upwards sequences of fine-medium lapilli tuffs change upwards to finemedium tuffs, in beds of less than $15 \mathrm{~cm}$ of thickness, with horizontal lamination and normal grading. (B) Type B3 volcaniclastic deposit. Detail of the previous image showing centimetre sequences of fine-medium lapilli-tuffs and fine-medium tuffs in beds with horizontal lamination, well sorting and with normal grading. (C) Type B4 volcaniclastic deposit. Fining-upwards sequences of well welded fine-medium lapilli tuffs (clear colours) in beds alternating with coarse-medium ash in dark colours. Strata with inverse and vertical dips. Arrows point to scatter bombs. (D) Type B4 volcaniclastic deposit. Detail of the previous image showing fine-medium lapilli tuffs and coarse-medium ash in clear and irregular transit with horizontal lamination and normal grading. (E) Type $\mathrm{C}$ volcaniclastic deposit. Conglomerate and breccias with clast-supported texture and showing massive or parallel bedding. (F) Erosive and channelled basal contact of the type $\mathrm{C}$ volcaniclastic deposit. Note that blocks and bombs are subrounded and with clast-supported textures. The deposit is massive or with horizontal stratification and with normal grading.

Fig. 10.- (A) Depósito volcanoclástico tipo B3. En esta imagen secuencias granodecrecientes de lapillis tobáceos de grano medio a fino cambian hacia la parte superior a tobas finas y medias, en capas de menos de $15 \mathrm{~cm}$ de espesor, con laminación horizontal y gradación normal. (B) Depósito volcanoclástico tipo B3. Detalle de la imagen anterior donde se ilustran secuencias centimétricas de lapillis tobáceos de grano medio a fino y tobas de grano fino a medio en capas con laminación horizontal, bien clasificadas y con gradación normal. (C) Depósito volcanoclástico tipo B4. Secuencias granodecrecientes de lapillis tobáceos de grano medio a fino bien soldados y colores claros que alternan con cenizas de grano grueso a medio en colores oscuros. Estratos con buzamientos inversos y verticales. Las flechas apuntan a bombas dispersas. (D) Depósito volcanoclástico tipo B4. Detalle de la fotografía anterior. Lapillis tobáceos de grano medio a fino y cenizas de grano grueso a medio en tránsito neto e irregular, mostrando laminación horizontal y gradación normal. (E) Depósito volcanoclástico tipo C. Conglomerados y brechas de textura clastoportada y estratificación masiva o paralela. (F) Contacto basal erosivo y canalizado del depósito volcanoclástico tipo C. Bloques y bombas subredondeadas y texturas clasto-soportadas. El depósito es masivo, con estratificación horizontal y gradación normal. 
the freshly developed maar crater rim.

The sedimentary features of the Type D deposit, namely well sorting, grain-size, matrix of deposits, inverse grading and absence of tractional sedimentary structures are in line with a deposit of an intra-maar scoria/spatter cones erupted in the maar crater that was developed right after maar formed. Likewise, the above sedimentary features indicate that the deposit is present in beds at the distal part of the scoria/spatter cones. This case is not an isolated example, since a small scoria mound in the base of a maar depression covered by maar lake deposits have been also reported in Hungary (e.g., Németh et al., 2008).

The post-eruptive episode of filling corresponds to a carbonated lacustrine succession deposited in a maar lake (Casablanca Maar). The lake water may have modified the texture of these materials with hydromorphic processes, dominated by hydrolysis caused by the migration and reduction of $\mathrm{Fe}$ ions. These ions became fixed in the sediments in the form of ferrous ions $\left(\mathrm{Fe}^{2+}\right)$, conferring a greenish colour on them.

\section{Discussion: factors controlling sedimentation}

Lithofacies analysis together with the use of paleogeographic, sedimentological, tectonic and geomorphological constraints may allow to establish those factors controlling sedimentation in intra-continental sedimentary basins with volcanic material supplies. In this particular scenario, magma-feeding paths in the CCVF, and hence the emplacement of the volcanoes, was directly controlled by regional structural lineaments, with main directions of N45-60E, N80-85E and N135-160E, where vents were mainly placed. A similar scenario has also been reported in West Eifel Volcanic Field (Germany) and in the Central Pannonian Basin (Hungary) (Büchel, 1993; Németh and Martin, 1999, respectively). Likewise, the reactivation of the above structural lineaments in the Calzada-Moral Basin triggered seismic activity, evidenced by gravel intrusions together with liquefaction, pillow and mushroom structures in volcaniclastic deposits (Rodríguez Pascua and Barrera, 2002), clearly conditioning these deposits.

Another crucial factor controlling sedimentation was the eruption style, which depends on the composition of the CCVF volcanoes (alkaline to ultrapotassic; e.g., Ancochea and Ibarrola, 1982). The main eruptive styles in the CCVF are explosive to effusive Strombolian and explosive phreatomagmatic (Ancochea, 1982, 2004; Cebriá, 1992). Explosive phreatomagmatic eruptions had an important role in the overall evolution of individual volcanoes of the CCVF, resulting in explosion craters with preserved tuff-rings in the sedimentary basins. In addition, these eruptions provided volcanic detritus to
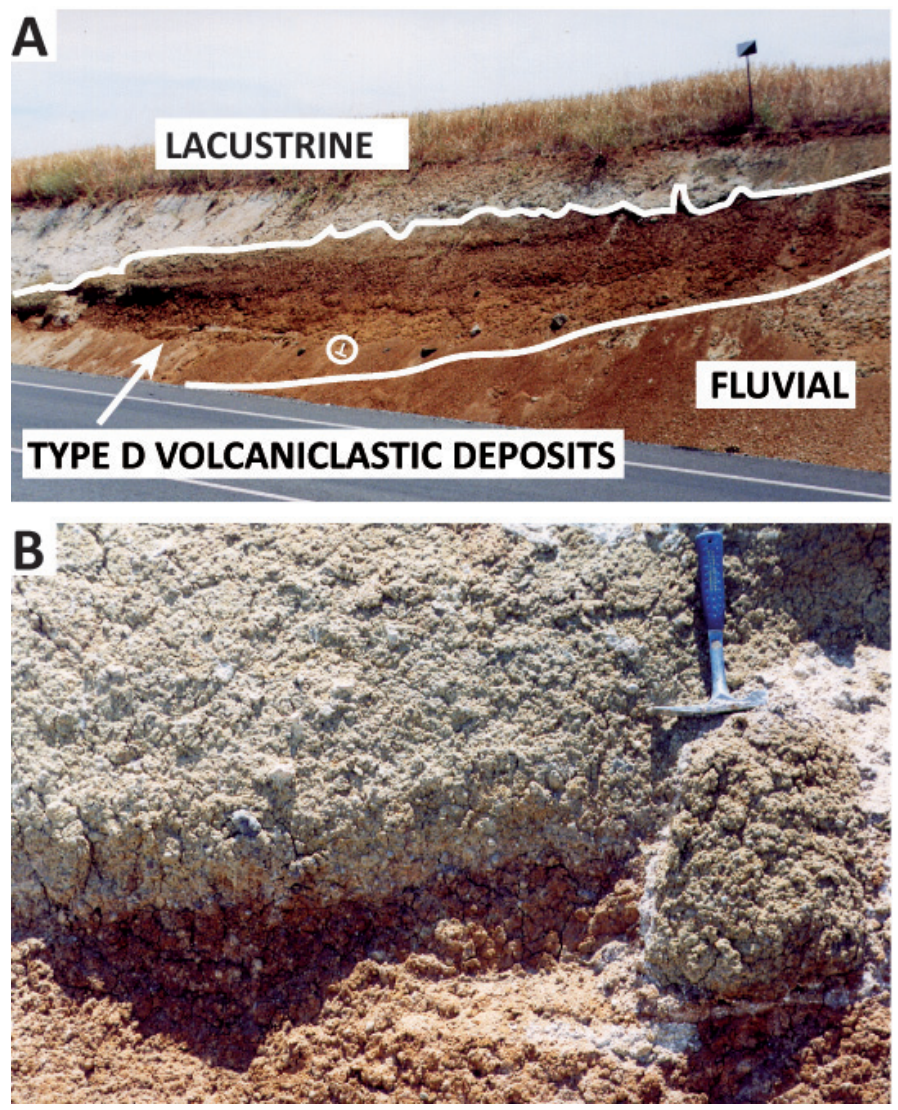

Fig. 11.- (A) Type D volcaniclastic deposit. Coarse-to-very coarse lapilli in a medium-to-coarse ash matrix at the sharp-erosive boundary. Note that the texture is matrix-supported and the occurrence of subrounded bombs and blocks up to $50 \mathrm{~cm}$ in diameter. The volcaniclastic deposits are interbedded between fluvial and lacustrine sediments (in the base and above, respectively). (B) Detail of the matrix-supported texture and the inverse grading. The transition from red to green at the top is a consequence of hydromorphic processes and is associated with an increase in grain size.

Fig. 11.- (A) Depósito volcanoclásticos tipo D. Lapillis de tamaño grueso a muy grueso en una matriz de ceniza de grano medio a grueso con un límite erosivo brusco. Nótese como la textura es matriz-soportada y la presencia de algunos bloques y bombas subredondeadas de hasta $50 \mathrm{~cm}$ de diámetro. El depósito volcanoclástico está emplazado entre sedimentos fluviales en la base y lacustres por encima. (B) Depósito volcanoclásticos tipo D. Detalle de la textura matriz-soportada y la gradación inversa. La transición del rojo al verde en la parte superior es debida a procesos de hidromorfía y está asociada a un aumento de tamaño de grano.

be incorporated in fluvial and normal lacustrine sedimentary processes. Explosive eruptions may also cause catastrophic processes in the sedimentary basins. In our case, the volcanism in both sedimentary basins resulted in changes in the fluvial drainage system, formation of depressions and the deposition of pyroclastic materials.

The changes in fluvial drainage system are evidenced by changes in the geometry and pattern of channels, modifications of paleocurrent directions and the creation of accommodation space and base-level adjustments. The depressions in the CCVF are abundant and scattered, re- 
sulting in lacustrine environments with a shallow carbonate-dominated sedimentation (e.g., profiles 1 and 7, Fig. 5). These depressions in the CCVF seem to be strongly controlled by the pre-volcanic environment, specifically, the so-called "hard-substrate" and "soft-substrate" (Ancochea, 1983; Poblete, 1995; Martín-Serrano et al., 2009). In the former, magma interacted with water in joint aquifers and the explosive volcanic processes extracted deep source country rock fragments, which along with juvenile fragments constitute a significant "exotic" debris source to local sedimentary basins (lava-flow, pyroclastic deposits, volcanic building). In the soft-substrate, the explosive volcanic processes affected poorly-consolidated sediments and maars and tuff rings redistributed fine-grained country rock fragments (sand and mud grains with various minerals), contributing to the total sedimentary budget of shallow maar pitted fluvio-lacustrine basins (e.g., Casablanca Maar-Lake, Fig. 8). The occurrence of salty playa lakes and rare evaporitic deposits in these basins suggests an arid/semi-arid climate in the area, similar to that described in the Hopi Buttes eruptive environments in Arizona (White, 1990).

Finally, the sedimentation of the aforementioned syneruption volcaniclastic lithofacies occurred in short pe-

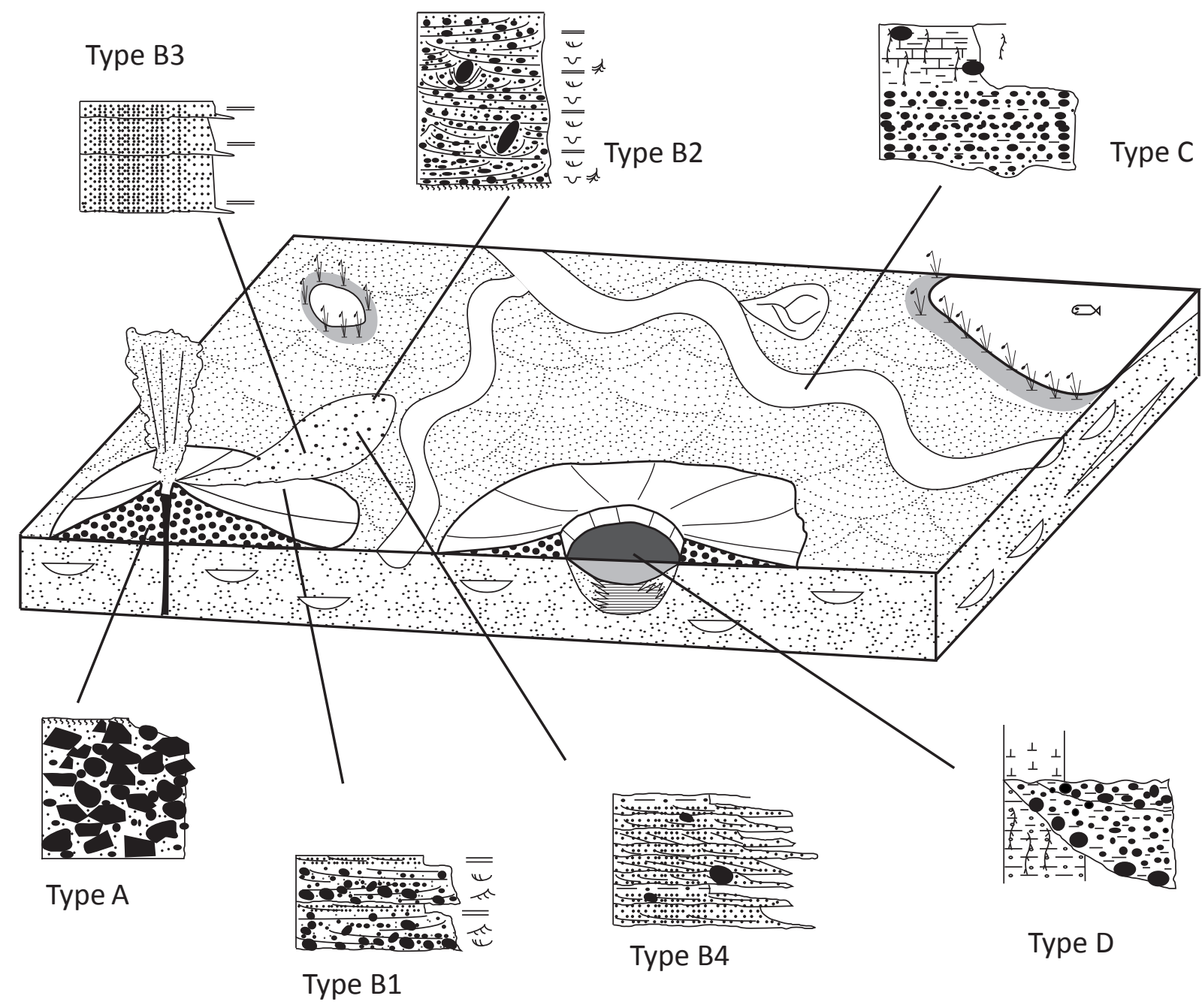

Fig. 12.- Sedimentological conceptual model and location of the different types of volcaniclastic deposits. The latter are inferred to be related to volcanic centres of small volume and monogenetic volcanoes such as scoria cones, tuff rings and maars. Type A volcaniclastic deposits are interpreted as subaerial pyroclastic fall deposits. Subtypes B1, B2, B3 and B4 volcaniclastic deposits are interpreted as the products of low-density (dilute) pyroclastic surges with different volcanic sources. Type C volcaniclastic lithofacies is a secondary volcanic sediment. Finally, Type D volcaniclastic deposits are interpreted as scoria/spatter cone deposits into the maar basins.

Fig. 12.- Modelo conceptual sedimentológico y ubicación de los diferentes tipos de depósitos volcanoclásticos. Estos últimos están relacionados con centros volcánicos de pequeño volumen y volcanes monogenéticos tales como, conos de escoria, anillos de tobas y maares. Los depósito volcaniclásticos de Tipo A se interpretan como depósitos de caída piroclástica subaérea. Los depósitos volcaniclásticos de los subtipos B1, B2, B3 y B4 se interpretan como los productos de oleadas piroclásticas de baja densidad (diluidas) con diferentes fuentes volcánicas. La litofacies volcaniclástica Tipo C corresponde a un sedimento volcánico secundario. Finalmente, los depósitos volcaniclásticos de Tipo D se interpretan como depósitos de conos de escoria/spatter dentro de maares. 
riods and with small thicknesses, separated by longer inter-eruption periods, where non-volcanic processes were dominant. The influence of volcaniclastic materials in sedimentation is evidenced in terms of source of materials and rapid and episodic aggradation, the latter inferred by the existence of small volcaniclastic layers interbedded between non-volcanic sediments.

\section{Conclusions}

The occurrence of volcano edifices into continental basins, exemplified by the Argamasilla and Calzada-Moral basins in the CCVF, has constituted an opportunity to address the influence of volcanism in intra-continental depositional environments, especially by the existence of periods of volcanic activity and quiescence providing an alternation of terrigenous and carbonated sediments with a varied sequence of primary and secondary volcaniclastic deposits. The stratigraphic analysis, the paleocurrent measures and other sedimentological features resulted to be very suitable tools to identify and correlate volcaniclastic deposits in both basins and to determine the deposition environment, the source of volcaniclastic materials and the processes involved. Volcanic breccia with poor sorting, uncharacteristic grading and a massive nature were interpreted as air fall deposits close to vents that developed scoria cones and rings around them (Type A). However, it seems likely that other air fall deposits (upper part of Type B4) are further from the vent, as inferred by the presence of coarse-medium ashes and mantle bedding laminations. The sedimentological analysis revealed the formation of abundant low velocity, dilute and turbulent phreatomagmatic base surges in both basins. The grain size and sedimentary structures indicated deposits from a proximal source in some cases (Type B1). In contrast, the finest grain size, together with the presence of bombs with ballistics projection and structures reflecting a lower flow stage are in line with a more distal source (Types B2, B3 and lower part of Type B4). Moreover, transitional hyperconcentrated flows and dilute fluvial processes seem to have played an important role in explaining the reworking of previous volcaniclastic deposits (Type C), as it is deduced by the normal grading and the occurrence of stratification that would exclude the participation of other mechanisms as proximal debris flow. Likewise, the development of maars in these sedimentary basins provided deposits with well sorting, inverse grading and absence of tractional sedimentary structures, being interpreted as intra-maar scoria/spatter cone deposits (Type D).

The volcaniclastic lithofacies studied in both basins allowed us to infer the type of volcanic eruption associated with the deposits, even if the volcanic edifice is poorly conserved, resulting in explosive phreatomagmatic and explosive and effusive Strombolian eruptions.

Sedimentation in both basins was strongly determined by the orientation of basement faults, paleogeographic and sedimentological intra-basinal controls, style of eruption and volcaniclastic deposit type. The first conditioned the emplacement of volcanic edifices. The second led to drainage-pattern disruption, the modification of sedimentological intra-basinal features, internal changes in fluvial system and the creation of shallow lakes (e.g., Casablanca Maar and Calzada de Calatrava). Finally, the eruption style together with its related deposits strongly controlled the input rate of these volcaniclastic deposits in the sedimentary basin.

\section{Acknowledgements}

This work is a contribution of the project: "Geological Cartography at a Scale of 1:50,000 of Map Numbers $150,181,182,214,215,253,605,629,630,660,687$, 688, 810, 811, 812, 865, 866 and 886" Programa 542 E, Superproyecto 9001, Cartografia Geológica y Temática, Proyecto Agregado 239 of the Instituto Geológico de España, IGME (Spanish Geological Survey). The authors are grateful to IGME for the facilities given to this work. We gratefully appreciate the suggestions, availability and facilities by Antonio Crespo Zamorano and Juan Carlos Gonzalo Corral (University of Salamanca). We are also grateful to Károly Németh (University of Otago) for critical reading of the manuscript and fruitful comments and suggestions, and Javier Martín-Chivelet for editorial handling.

\section{References}

Ancochea, E. (1982): Evolución espacial y temporal del vulcanismo reciente de España Central. Ph.D Thesis, Universidd Complutense de Madrid, $675 \mathrm{pp}$.

Ancochea, E. (1983): Enclaves ultramáficos de la Región Volcánica Central Española. Revista de Materiales y Procesos Geológicos 1, 337-339.

Ancochea, E. (2004): La región volcánica del Campo de Calatrava. In: Vera J. A. (ed.), Geología de España. Sociedad Geológica de España and Instituto Geológico y Minero de España, Madrid, 676-677.

Ancochea, E., Ibarrola, E. (1982): Caracterización geoquímica del vulcanismo de la región volcánica central española. Boletín Real Sociedad Española de Historia Natural (Geología), 80: 57-88.

Ancochea, E., Giuliani, A., Villa, I. (1979): Edades radiométricas K/ Ar del vulcanismo de la Región Central Española. Estudios Geológicos 35, 131-135.

Barrera, J.L. (1996): Unpublished Report. Consejería de Agricultura y Medio Ambiente. Junta de Comunidades de Castilla-La Mancha, $80 \mathrm{pp}$.

Bonadonna, F.P., Villa, J.M. (1984): Estudio geocronológico del volcanismo de Las Higueruelas. I Reunión Estudios Regionales Castilla-La Mancha, Actas, 3, 49-253.

Branney, M.J., Kokelaar, P. (2002): Pyroclastic Density Currents and 
the Sedimentation of Ignimbrites. Geological Society Londn, Memoirs 27, $143 \mathrm{pp}$.

Büchel, G. (1993): Maars of the Westeifel, Germany. In: J.F.K. Negendank y B. Zolitschka (eds.), Paleolimnology of European Maar Lakes, Springer-Verlag, 1-13. doi: 10.1023/A:1007980201890.

Cajz, V; Rapprich, V; Erban, V; Pécskay Z., Radoň, M., (2009): Late Miocene volcanic activity in the České středohoří Mountains (Ohře/Eger Graben, northern Bohemia). Geologica Carpathica 60, 519-533. . doi: 10.2478/v10096-009-0038-8.

Carey, S.N. (1991): Transport and deposition of tephra by pyroclastic flows and surges. In: Fisher RV, Smith GA (eds.). Sedimentation in Volcanic Settings, SEPM Special Publication 45, 39-57. doi: 10.2110/pec.91.45.0039.

Cas, R.A.F., Wright, J.V. (1987): Volcanic successions modern and ancient. Allen and Unwin, London, 528 pp.

Cebriá Gómez, J.M. (1992): Geoquímica de las rocas basálticas y leucititas de la región volcánica de Campo de Calatrava, España. Ph.D Thesis, University Complutense de Madrid, 314 pp.

Cole, P.D. (1991): Migration direction of sand-wave structures in pyroclastic-surge deposits: implications for depositional processes. $\mathrm{Ge}$ ology 19, 1108-1111. doi: 10.1130/0091-7613(1991)019<1108:MD OSWS $>2.3 . \mathrm{CO} ; 2$.

Crespo, A. (1988): Primeras notas sobre los yacimientos de manganeso cobaltífero en el Plioceno del Campo de Calatrava (Ciudad Real). Boletín de la Sociedad Española de Mineralogía 11, 149152.

Crespo, A. (1992): Geología, mineralogía y génesis de los yacimientos de manganeso cobaltíferos del Campo de Calatrava (Ciudad Real). Ph.D Thesis, University Complutense de Madrid, 389 pp.

Dellino, P., Isaia, R., Veneruso, M. (2004 a): Turbulent boundary layer shear flows as an approximation of base surge at Campi Flegrei (Southern Italy). Journal of Volcanology and Geothermal Research 133, 211-228. doi:10.1016/S0377-0273(03)00399-8.

Dellino, P., Isaia, R., La Volpe, L., Orsi, G. (2004 b): Interaction between particles transported by fallout and surge in the deposits of the Agnano-Moste Spina eruption (Campi Flegrei, Southern Italy). Journal of Volcanology and Geothermal Research 133, 193-210. doi:10.1016/S0377-0273(03)00398-6.

Di Traglia, F., Cimarelli, C., de Rita, D., Gimeno Torrente, D. (2009): Changing eruptive styles in basaltic explosive volcanism: Examples from Croscat complex scoria cone, Garrotxa Volcanic Field (NE Iberian Peninsula). Journal of Volcanology and Geothermal Research 180, 89-109. doi:10.1016/j.jvolgeores.2008.10.020

Doblas, M., López Ruíz, J., Hoyos, M., Martín, C., Cebriá, J.M. (1991): Late Cenozoic indentation/escape tectonics in the eastern Betic cordilleras and its consequences on the Iberian foreland. Estudios Geológicos 47, 193-205.

Druitt, T.H. (1998): Pyroclastic density currents. In: Gilbert JS. and Sparks RSJ. (eds), The Physics of Explosive Volcanic Eruptions. Geological Society, London, Special Publications 145, 145-182. doi:10.1144/GSL.MEM.2002.021.01.09.

Eriksson, K.A., Simpson, E.L. (1993): Braided-alluvial sedimentation in a mafic volcanic setting: tectonic implications. Special Publication International Association Sedimentologists 17, 473-488.

Eynon, G., Walter, R.G. (1974): Facies relationships in Pleistocene outwash gravels, southern Ontario: a model for bar growth in braid bars. Sedimentology 21, 43-70. doi: 10.1111/j.1365-3091.1974. tb01781.x

Fisher, R.V., Schmincke, H.U. (1984): Pyroclastic Rocks. SpringerVerlag. Berlin, 472 pp.

Fisher, R.V., Schmincke, H.U. (1994): Volcaniclastic sediment transport and deposition. In: Sediment transport and depositional processes, K. Pye (ed.). Blackwell Scientific Publications, 351-388 pp.
Gallardo-Millán, J.L. (2004): Evolución geodinámica de las cuencas neógenas del Campo de Calatrava (Ciudad Real) y su relación con el volcanismo reciente. Ph.D Thesis, Universidad Complutense de Madrid, $322 \mathrm{pp}$.

Gallardo-Millán, J.L., Pérez-González, A. (2000): Magnetoestratigrafía del relleno neógeno en las cuencas del Campo de Calatrava (Ciudad Real). Geotemas 1, 101-104.

Gallardo-Millán, J.L., Ancochea, E., Pérez González, A. (2002): Secuencia magnetoestratigráfica y edad de los materiales volcánicos y sedimentarios de Poblete (Ciudad Real). Geogaceta 32, 35-38.

González-Cárdenas, E., Gosálvez-Rey, R., Becerra-Ramírez, R., and Escobar-Escobar, E. (2007): Actividad eruptiva holocena en el Campo de Calatrava (Volcán Columba, Ciudad Real, España). In: Lario, J. y Silva, P.G. (eds). Contribuciones al estudio del período cuaternario. AEQUA. 143-144 pp.

González-Cárdenas, E., Gosálvez-Rey, R., Becerra-Ramírez, R., and Escobar-Escobar, E. (2008): Facies laháricas en los depósitos de oleadas piroclásticas del 'Barranco Varondillo', Campo de Calatrava (España). In: J. Benavente y F. J. Gracia (eds.). Trabajos de Geomorfología en España, 2006-2008. SEG, Cádiz, 25-28 pp.

Gran, K.B., Montgomery, D.R. (2005): Spatial and temporal patterns in fluvial recovery following volcanic eruptions: Channel response to basin-wide sediment loading at Mount Pinatubo, Philippines. Geological Society of American Bulletin 117, 195-211. doi: 10.1130/ B25528.1

Haughton, P.D.W. (1993): Simultaneous dispersal of volcaniclastic and non-volcanic sediment in fluvial basin: examples from Lower Old Red Sandstone, eats-central Scotland. Special Publication International Association Sedimentologists 17, 451-471.

Hayes, S.K., Montgomery, D.R., Newhall, C.G. (2002): Fluvial sediment transport and deposition following the 1991 eruption of Mount Pinatubo. Geomorphology 45, 211-224. doi:10.1016/S0169555X(01)00155-6.

Herrero, A., Alonso Gavilán, G., Colmenero, J.R. (2004 a): Estratigrafía del subsuelo en el sector noroeste de la cuenca del Duero (Provincia de León). Revista de la Sociedad Geológica de España 17, 199-216.

Herrero, A., Martín Banda, R., Martín-Serrano, A. (2004 b): Facies fluviales y lacustres de los sedimentos finineógenos de Valdepeñas, Ciudad Real (SO de la Llanura Manchega). Geogaceta 35, 39-42.

Herrero, A., Alonso Gavilán, G., Colmenero, J.R. (2009): Depositional sequences in a foreland basin (north-western domain of the continental Duero basin, Spain). Sedimentary Geology 223, 235-264. DOI:10.1016/j.sedgeo.2009.11.012

Kataoka, K. (2005): Distal fluvio-lacustrine volcaniclastic resedimentation in response to an explosive silicic eruption: The Pliocene Mushono tephra bed, central Japan. Geological Society of American Bulletin 177, 3-17. doi: 10.1130/B25379.1.

Kereszturi, G., Németh, K., Csillag, G., Balogh, K. Kovács, J. (2011): The Role of External Environmental Factors in Changing Eruption Styles of Monogenetic Volcanoes in a Mio/Pleistocene Continental Volcanic Field in Western Hungary. Journal of Volcanology and Geothermal Research 201, 227-240. doi:10.1016/j. jvolgeores.2010.08.018.

López Ruíz, J., Cebriá, J.M., Doblas, M. (2002): Cenozoic volcanism I: the Iberian peninsula. In: W. Gibbons, T. Moreno (eds.), The Geology of Spain. Geological Society, London: 417-438

López Ruíz, J., Cebriá, J.M., Doblas, M., Oyarzun, R., Hoyos, M., Martín, C. (1993): Cenozoic intraplate volcanism related to extensional tectonics at Calatrava Central Iberia. Journal Geological Society 150, 915-927. doi: 10.1144/gsjgs. 150.5.0915.

Lustrino, M., Wilson, M. (2007): The circum-Mediterranean anorogenic Cenozoic igneous province. Earth-Science Reviews 81, 1-65. 
doi: 10.1016/ j.earscirev.2006.09.002.

Lustrino, M., Duggen, S., Rosenberg, C.L. (2011): The CentralWestern Mediterranean: Anomalous igneous activity in an anomalous collisional tectonic setting. Earth-Science Reviews 104, 1-40. doi:10.1016/j.earscirev.2010.08.002.

Manville, V.; Németh, K.,Kano, K. (2009): Source to Sink: A Review of Three Decades of Progress in the Understanding of Volcaniclastic Processes, Deposits, and Hazards. Sedimentary Geology.220, 136-161. doi:10.1016/j.sedgeo.2009.04.022.

Martín Banda, R., Monteserín, V., Martín-Serrano, A., Herrero, A., Rey, C. (2011): Estratigrafía. In: Memoria del Mapa Geológico de España, Scale 1:50.000, 2nd series, no. 812, Valdepeñas. Madrid, Instituto Geológico y Minero de España, 50 pp.

Martina, F., Dávila, F.M., Astini, R.A. (2005): Mio-Pliocene volcaniclastic deposits in the Famantina Ranges, Southern Central Andes: A case of volcanic control on sedimentation in broken foreland basins. Sedimentary Geology 186, 51-65. doi:10.1016/j. sedgeo.2005.10.002.

Martín-Serrano, A., Monteserín, V., Ancochea, E., Herrero, A., Rey, C. (2011): Estratigrafía. In: Memoria del Mapa Geológico de España, Scale 1:50.000, 2nd series, $n^{\circ}$. 811, Moral de Calatrava. Madrid, Instituto Geológico y Minero de España, 59 pp.

Martín-Serrano, A., Vegas, J., García-Cortés, A., Galán, L., GallardoMillán, J.L., Martín-Alfageme, S., Rubio, F.M., Ibarra, P.I., Granda, A., Pérez-González, A., García-Lobón, J.L. (2009): Morphotectonic setting of maar lakes in the Campo de Calatrava Volcanic Field (Central Spain, SW Europe). Sedimentary Geology 222, 52-63. doi:10.1016/j.sedgeo.2009.07.005

Mcgowen, J.H., Groat, C.G. (1971): Van Horn Sandstone, west Texas: an alluvial fan model for mineral exploration. Bureau of Economic Geology, Report of Investigations 72, $57 \mathrm{pp}$.

McPhie, J., Doyle, M., Allen, R. (2001): Volcanic Textures. Elsevier, $345 \mathrm{pp}$.

Miall, A.D. (1977): A review of the braided river depositional environment. Earth Science Review 13, 1-62. doi:10.1016/00128252(77)90055-1.

Miall, A.D. (1978): Lithofacies types and vertical profile models in braided river deposits: a summary. In: Miall A. D. (ed.), Fluvial Sedimentology. Canadian Society of Petroleum Geologists Memoir, 5, 597-604.

Miall, A.D. (1992): Alluvial deposits. In: Walker RG, James NP (eds.), Facies models. Response to sea level change. Geological Association of Canada, 119-142 pp.

Molina, E. (1975): Estudio del Terciario superior y del Cuaternario del Campo de Calatrava. Trabajos sobre Neógeno-Cuaternario 3, 7-106.

Molina, E. (1980): Alteración relicta y morfogénesis del macizo cristalino de Toledo. Stvdia Geologica Salmanticensia 22, 293-307.

Molina, E., Pérez González, A., Aguirre, E. (1972): Observaciones geológicas del Campo de Calatrava. Estudios Geologicos 27, 3-11.

Monteserín, V., Martín-Serrano, A., Herrero, A., Ancochea, E., Rey, C. (2011): Estratigrafia. In: Memoria del Mapa Geológico de España, Scale 1:50.000, 2nd series, $n^{\circ}$. 810, Puertollano. Madrid, Instituto Geológico y Minero de España, 60 pp.

Németh, K. (2010): Monogenetic Volcanic Fields: Origin, Sedimentary Record, and Relationship with Polygenetic Volcanism In: CañónTapia, E., Szakács, A. (Eds.), What Is a Volcano?. Geological Society of America Special Papers 470, 43-67. doi:10.1130/2010.2470(04).

Németh, K., Martin, U. (1999): Small-volume volcaniclastic flow deposits related to phreatomagmatic explosive eruptive centres near Szentbékkálla, Bakony- Balaton Highland Volcanic Field Hungary: Pyroclastic flow or hydroclastic flow? Földtani Közlöny, Budapest. Bulletin of the Hungarian Geological Society 129 (3), 393-417.
Németh, K., Cronin, S. J. (2007): Syn- and post-eruptive erosion, gully formation, and morphological evolution of a tephra ring in tropical climate erupted in 1913 in West Ambrym, Vanuatu. Geomorphology, 86, 115-130. doi:10.1016/j.geomorph.2006.08.016.

Németh, K., Martin, U. (2007): Shallow sill and dyke complex in western Hungary as a possible feeding system of phreatomagmatic volcanoes in "soft-rock" environment. Journal of Volcanology and Geothermal Research 159, 138-152. DOI 10.1016/j.jvolgeores.2006.06.014.

Németh, K., Goth, K., Martin, U., Csillag, G., Suhr, P. (2008): Reconstructing paleoenvironmental, eruption mechanism and paleomorphology of the Pliocene Pula maar, (Hungary). Journal of Volcanology and Geothermal Research 177, 441-456. doi:10.1016/j. jvolgeores.2008.06.010.

Németh, K., Cronin, S. J., Stewart, R. B., Charley, D. (2009): Intraand extra-caldera volcaniclastic facies and geomorphic characteristics of a frequently active mafic island-arc volcano, Ambrym Island, Vanuatu. Sedimentary Geology, 220, 256-270. doi:10.1016/j. sedgeo.2009.04.019.

Palero, F.J. (1991): Evolución geotécnica y yacimientos minerales de la región del Valle de Alcudia (Sector Meridional de la Zona Centroibérica). Ph.D Thesis, University of Salamanca, Salamanca, 579 pp.

Poblete, M.A. (1995): El relieve volcánico del Campo de Calatrava (Ciudad Real). Junta de Comunidades de Castilla-La Mancha, Ed., Gijón, 125 pp.

Rincón, P.J., Vegas, R. (1996): Geotectónica en el antepaís castellano de las cordilleras béticas orientales. Geogaceta 20, 929-931.

Rodríguez Pascua, M.A., Barrera, J.L. (2002): Estructuras paleosísmicas en depósitos hidromagmáticos del vulcanismo del Campo de Calatrava, Ciudad Real (España). Geogaceta 32, 39-42.

Rosales, F., Torres, T., Méndez, J., Saviron, L., Alberdi, R., Campo, M., Sánchez, A. (1988): Investigación geofísica en La Mancha de Ciudad Real. Actas del VIII Congreso Internacional de Minería y Metalurgia. Oviedo. 316-333 pp.

Seib, N., Kley, J., Torizin, J., Zander, I., Goepel, A. \& Büchel, G. (2008): Identification of volcanic forms in a digital terrain model (DGM) of West Eifel._Zeitschrift der Deutschen Gesellschaft fur Geowissenschaften 159, 657-670. DOI: 10.1127/18601804/2008/0159-0657

Sheridan, M.F., Wohletz, K.H. (1981): Hydrovolcanism eruptions I. The systematics of water-pyroclastic equilibration. Science 212, 1387-1389. doi:10.1126/science.212.4501.1387.

Sheridan, M.F., Wohletz, K.H. (1983): Hydrovolcanism: basic considerations and review. Journal of Volcanology and Geothermal Research 17, 1-29. doi:10.1016/0377-0273(83)90060-4.

Smith, G.A. (1987): Sedimentology of volcanism-induced aggradation in fluvial basin: examples from the Pacific Northwest, USA. In: Ethridge FG, Flores RM, Harvey MG (eds.), Recent developments in fluvial sedimentology. SEPM Special Publication, 39, 217-228.

Smith, G.A. (1991): Facies sequences and geometries in continental volcaniclastic sediments. In: Fisher RV, Smith GA (eds.), Sedimentation in Volcanic Settings. SEPM Special Publication, 45, 109-121.

Sparks, R.S.J. (1976): Grain size variation in ignimbrites and implications for the transport of pyroclastic flows. Sedimentology 23, 147188. doi:10.1111/j.1365-3091.1976.tb00045.x.

Sparks, R.S.J., Walker, G.P.L. (1973): The ground surge deposit: a third type of pyroclastic rock. Nature 241, 62-64. doi:10.1038/physci241062a0.

Valentine, G.A., Gregg, T.K.P. (2008): Continental basaltic volcanoes - processes and problems. Journal of Volcanology and Geothermal Research 177, 857-873. doi:10.1016/j.jvolgeores.2008.01.050.

Valentine, G.A., Krier, D., Perry, F.V., Heiken, G. (2005): Scoria cone 
construction mechanisms, Lathrop Wells volcano, southern Nevada, USA. Geology 33, 629-632. doi:10.1130/G21459AR.1.

Vesperman, D., Schmincke, H.U. (2000): Scoria cones and tuff rings. In: Sigurdsson, H. (Ed.), Encyclopedia of Volcanoes. Academic Press, San Diego, pp. 683-694.

Walker, G.P.L. (1983): Ignimbrites types and ignimbrite problems. Journal of Volcanology and Geothermal Research 17, 65-88. doi:10.1016/0377-0273(83)90062-8.

White, J.D.L. (1990): Depositional Architecture of a Maar-Pitted Playa - Sedimentation in the Hopi Buttes Volcanic Field, Northeastern Arizona, USA. Sedimentary Geology, 67, 55-84. doi:10.1016/00370738(90)90027-Q.

White, J.D.L. (1991): The Depositional Record of Small, Monogenetic Volcanoes within Terrestrial Basins, In Fisher R.V. and Smith,
G.A. (Eds.), Sedimentation in Volcanic Settings. Society for Sedimentary Geology, Tulsa (Oklahoma), 155-171 pp.

Wilson, M., Downes, H. (1991): Tertiary-Quaternary extensionrelated alkaline magmatism in western and central Europe. Journal of Petrology 32, 811-849. doi: 10.1093/petrology/32.4.811.

Wohletz, K.H. (1993): Hidrovolcanismo. In: Martí J, Araña V (eds.), La volcanología actual. Consejo Superior de Investigaciones Científicas, Madrid, 99-195 pp.

Wohletz, K.H. (1998): Pyroclastic Surges and Compressible TwoPhase Flow. In: Freundt A, Rosi M (eds.), From magma to tephra: modelling physical processes of explosive volcanic eruptions. Developments in volcanology 4, Amsterdam. Elsevier, 318 pp.

Wohletz, K.H., Sheridan, M.F. (1979): A model of pyroclastic surge. Geological Society of America, Special Paper 180, 177-194. 